\title{
CFO Promotion-Based Incentives and Earnings Management
}

\author{
Ruonan Liu \\ University of the Pacific \\ rliu@pacific.edu
}

Steve Lin

The University of Memphis

swlin@memphis.edu

Changjiang Wang

The University of Cincinnati

wang2cj@ucmail.uc.edu 


\title{
CFO Promotion-Based Incentives and Earnings Management
}

\begin{abstract}
This study examines whether CFO promotion-based incentives induce opportunistic reporting activities. We find that $\mathrm{CFO}$ promotion-based incentives, measured by the pay gap between the $\mathrm{CEO}$ and the $\mathrm{CFO}$, are positively associated with accruals management and accounting misconduct in the pre-SOX period and the probability of meeting or beating analysts' forecasts in both pre- and post-SOX periods. Further analysis shows that CFO promotion-based incentives are negatively associated with real earnings management in both pre- and post-SOX periods. In addition, we find some evidence that the association between CFO promotion-based incentives and opportunistic reporting activities is stronger before CEO turnovers. We also document that CFOs engage in more opportunistic financial reporting when the pay gap between the CFO and other VPs is greater. Overall, our findings suggest that CFO promotion-based incentives may encourage CFOs to engage in opportunistic reporting activities but mitigate real earnings management.
\end{abstract}

Key Words: Promotion-based Incentives, Pay Gap, CEO, CFO, Earnings Management, Executive Compensation 


\section{首席财务官基于晋升的激励和盈余管理}

摘要

本文研究 CFO 基于晋升 $\mathrm{CEO}$ 职位的激励是否诱发投机性财务报告活动。我们以 $\mathrm{CEO}$ 和 $\mathrm{CFO}$ 之间的薪酬差距衡量 CFO 基于晋升 CEO 职位的激励。我们发现 CFO 基于晋升的激 励与 SOX 之前的应计盈余管理和会计不当行为以及在 SOX 之前和之后达到或超过分析师 预期盈余的可能性呈正相关。进一步的分析显示, CFO 基于晋升的激励与在 SOX 之前和 之后的真实盈余管理呈负相关。此外，一些证据表明 CFO 基于晋升的激励与投机性报告 活动之间的关联在 CEO 离职之前更显著。我们还发现, 当 CFO 与其他副总裁之间的薪酬 差距更大时, $\mathrm{CFO}$ 会参与更多的投机性财务报告。总体而言, 我们的调查结果显示, $\mathrm{CFO}$ 基于晋升职位的激励可能会鼓励 $\mathrm{CFO}$ 进行投机性的财务报告活动, 但会减轻真实盈 余管理活动。

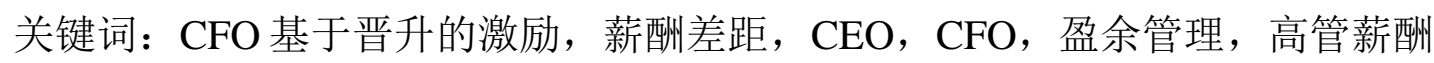




\section{INTRODUCTION}

Excessive CEO pay and the pay gap between the CEO and other senior executives (VPs) have attracted extensive attention from financial media, regulators, practitioners, and academics. Tournament theory provides one explanation to rationalize the large discrepancy in pay between the CEO and VPs (Lazear and Rosen, 1981). Tournament theory states that VPs compete for the promotion just as contestants compete for a fixed set of prizes in a tournament, where larger prizes result in greater efforts (Prendergast, 1999). In the context of managerial compensation, a larger pay gap between the CEO and VPs can motivate VPs to exert greater effort to compete for the CEO position. However, the literature has provided mixed evidence about whether and how VP promotion-based incentives affect firm performance and firm value. ${ }^{1}$ Kale, Reis, and Venkateswaran (2009) find that VP promotion-based incentives, measured by the pay gap between the CEO and VPs, are positively associated with firm performance and firm value. In contrast, several studies provide evidence that large pay gaps may negatively affect firms' policies and performance (e.g., Henderson and Fredrickson, 2001; Kini and Williams, 2012; Park, 2017). For example, Kini and Williams (2012) document that the pay gap between the CEO and VPs is positively associated with riskier firm policies. Similarly, Park (2017) finds that the pay gap between the CEO and VPs is positively associated with real earnings management.

Prior studies primarily focus on the pay gap between the CEO and VPs and examine its impact on firm performance, firm value, corporate investing, financing, and operating activities (e.g., Kale et al., 2009; Kini and Williams, 2012; Park, 2017; Vo and Canil, 2019). Different from these studies, we focus on the pay gap between the CEO and the CFO and investigate the impacts of CFO promotion-based incentives on firms' financial reporting activities, which fall in the domain of the responsibilities of CFOs. This is an important issue for the following reasons. 
First, CFOs may stand out as un-replaceable leaders for their firms and competitive candidates for the CEO position due to their financial expertise. CFOs have superior knowledge and experience in making financial decisions; they are also responsible for raising capital and communicating firm performance with outsiders (Mian 2001). In addition, besides CEOs, CFOs are able to answer questions regarding firms' operating, financing, and investment plans from shareholders, potential investors, financial analysts, and the press. Thus, CFOs play a critical role in communicating between their firms, shareholders, and other interest parties. ${ }^{2}$ Even if CFOs are not promoted by their firms, these advantages may eventually reward them the rank of CEO elsewhere.

Second, since CFOs are directly responsible for financial reporting decisions, they certainly have the incentives and opportunities to manage earnings (e.g., Ge, Matsumoto, and Zhang 2010, Jiang, Petroni, and Wang 2010).

Finally, previous studies have documented the impacts of CEO and CFO equity incentives on earnings management and largely ignore the role of CFOs' promotion-based incentives in opportunistic reporting activities. For example, prior research documents that CEO equity incentives are associated with accruals management (Bergstresser and Philippon, 2006), the probability of restatement (Burns and Kedia, 2006), and meeting or beating analysts' forecasts (Cheng and Warfield, 2005). Chava and Purnanandam (2010) find that CFO risk-aversion (increasing) incentives are associated with higher (lower) earnings smoothing through accounting accruals. Several studies examine the relative role of CEOs and CFOs in opportunistic reporting activities, although the results appear to be mixed (Jiang et al., 2010; Feng, Ge, Luo, and Shevlin, 2011). 
In addition to the equity incentives of CFOs, we expect the promotion-based incentives also motivate CFOs to engage in earnings management. However, promotion-based incentives may or may not be strong enough to induce CFOs to undertake earnings management. This is because CFOs need to improve their experience and skillsets outside the accounting and finance function to become viable candidates for the CEO position, according to a consulting firm Spencer Stuart. Indeed, only less than 5\% of the CFOs in our sample were eventually promoted to the CEO from within the firms. In other words, even if CFOs have some competitive edge among VPs, they may not get promoted to the CEO. Previous research shows that many CFOs left for other firms after CEO turnovers (Geiger and North 2006).

Using data from 1993 to $2018^{3}$, we find that CFO promotion-based incentives are positively associated with accruals management and accounting misconduct in the pre-SOX period. We also find that CFO promotion-based incentives are positively associated with the likelihood of meeting or beating analysts' forecasts in both pre- and post-SOX periods. Furthermore, we document that $\mathrm{CFO}$ promotion-based incentives are negatively associated with real earnings management in both pre- and post-SOX periods. Our results are robust after controlling for CFO and CEO equity incentives and CEO power, measured by CEO pay slice, and CEO-Chairman duality. We also find some evidence that the association between CFO promotion-based incentives and aggressive reporting activities is stronger before CEO turnovers. Finally, we observe that CFOs engage in more opportunistic financial reporting when the pay gap between the CFO and other VPs is greater.

This study contributes to the literature in threefold. First, we extend previous studies on tournament theory and find that CFO promotion-based incentives are associated with opportunistic reporting activities. Second, we add to the literature focusing on the relative role of CEOs and 
CFOs in earnings management. We note that not only the equity incentives but also the promotionbased incentives are driving CFOs to engage in opportunistic reporting activities. Finally, we document the mitigating effect of CFO promotion-based incentives on real earnings management.

The remainder of the paper is organized as follows: Section 2 reviews related literature and develops our hypotheses, Section 3 presents our empirical design, Section 4 discusses the data and our empirical results, and Section 5 concludes.

\section{LITERATURE REVIEW AND HYPOTHESES DEVELOPMENT}

Previous studies have provided evidence that CFOs play a key role in financial reporting. For example, Geiger and North (2006) show that discretionary accruals decrease significantly surrounding the appointment of a new CFO, indicating that CFOs have a significant and independent influence on firms' reporting quality from CEOs. Ge et al. (2010) provide evidence that accounting choices are influenced by the individual characteristics of CFOs such as their dispositions, personal situations, and prior experiences. In addition, Chava and Puranandam (2010) find that CFOs' risk-aversion incentives are associated with higher earnings smoothing.

The equity incentives of CEOs and CFOs to manage earnings have been widely examined in the literature. Bergstresser and Philippon (2006) find that CEO equity incentives, measured as the sensitivity of the CEO wealth to one percent change in firms' stock price, are positively associated with the absolute value of discretionary accruals. Cheng and Warfield (2005) document that CEO equity incentives are positively related to the likelihood of meeting or beating analysts' forecasts. Burns and Kedia (2006) examine all the components of CEO compensation and find that the sensitivity of the option portfolio to stock price impacts the propensity of financial statement restatements. 
Two studies examine the relative role of CEOs and CFOs in accounting manipulations. Jiang et al. (2010) find that CFO equity incentives are positively associated with accruals management after controlling for CEO equity incentives in the pre-SOX period. They also find that $\mathrm{CFO}$ equity incentives, rather than $\mathrm{CEO}$ equity incentives, dominate the association with meeting or beating analysts' forecasts in both pre- and post- SOX periods. In contrast, Feng et al. (2011) investigate whether CFO's involvement in material accounting manipulations is caused by the pressure from CEOs instead of CFOs' equity holdings. ${ }^{4}$ They point out that only CEO equity incentives and CEO power, measured by CEO pay-slice, CEO founder, and CEO-Chairman duality, are positively associated with the occurrence of material accounting manipulations.

Little research, however, has investigated whether CFOs' opportunistic reporting behavior is related to their promotion-based incentives. Tournament theory predicts that larger promotion prizes lead to greater effort to win the prizes in firms, just like a sports game (Prendergast, 1999). Lazear and Rosen (1981) use tournament theory to examine the incentives generated by the pay gap among different ranks of contestants in the firm. Green and Stokey (1983) also use tournament theory to examine the incentives provided by promoting workers to different ranks of positions. A growing body of literature has studied VP promotion-based incentives, which are normally measured by the pay difference between the CEO and VPs (Bognanno, 2001). Kale et al. (2009) find that after controlling for the CEO and VP equity incentives, VP promotion-based incentives are associated with better short- and long-term firm performance and firm value, measured by ROA and firm's Tobin's q, respectively. ${ }^{5}$ However, due to the fierce competition between VPs, VPs may take risky policies and strategies to inflate firm performance in order to increase their chances of promotion, which can eventually jeopardize firm value (Henderson and Fredrickson, 2001; Kini and Williams, 2012; Park, 2017). Consistent with this view, Kini and Williams (2012) 
document that VP promotion-based incentives are positively associated with firm risk, proxied by stock return volatility, and seasonally adjusted cash flow volatility. They also find that tournament incentives are associated with higher R\&D propensity, firm focus and leverage but associated with lower capital expenditure propensity, suggesting that VPs' tournament incentives increase firm risk through riskier operating and financing policies. ${ }^{6}$ Park (2017) also observes a positive association between VP promotion-based incentives and real activity management. ${ }^{7}$

Kale et al. (2009) argue that promotion-based incentives arise due to the size of the pay gap between the CEO and VPs and the chance of VPs being promoted. Since CFOs are competitive candidates due to their financial expertise, they may be motivated by the large pay gap with CEOs to engage in opportunistic reporting activities in order to increase their chances of promotion. Therefore, we predict (in null hypothesis form):

Hla: CFO promotion-based incentives are not associated with firms' accruals management.

H1b: CFO promotion-based incentives are not associated with the likelihood of meeting or beating analysts' forecasts.

H1c: CFO promotion-based incentives are not associated with the likelihood of accounting misconduct.

We also extend the analysis to real earnings management as previous studies find that real earnings management substitutes accruals management when accruals management becomes more scrutinized following the Sarbanes-Oxley Act (Cohen, Dey, and Lys, 2008). Real earnings management affects the firm's underlying operations and may have a negative effect on the firm's long-term performance (Roychowdhury, 2006), while accruals management involves within GAAP accounting choices which do not affect the firm's operations. Hence, the role of CFOs plays 
in real earnings management may be different from that in accruals management. Duellman, Ahmed, and Abdel-Meguid (2013) find a negative relationship between CEO equity incentives and real earnings management, suggesting CEO equity incentives align the CEO's and the firm's long-term interests. However, Park (2017) finds real earnings management is positively associated with the pay gap between the CEO and VPs, while negatively associated with the long-term pay gap between the CEO and the CFO. We, therefore, predict (in the form of the null hypothesis):

H2: CFO promotion-based incentives are not associated with real earnings management.

\section{EMPIRICAL DESIGN}

Following Kale et al. (2009) and Kini and Williams (2012), we calculate CFO promotionbased incentives, CFO_Promo_Incent, as the natural logarithm of the pay difference between the CEO and the CFO. We follow Bergstresser and Philippon (2006) to calculate CFO equity incentives, CFO_Equity_Incent. We first calculate the change in the value of the CFO's stock and stock options portfolio in response to a one percent change in stock price. When estimating the sensitivity of stock options to stock price (delta), we follow Core and Guay (2002) to estimate delta separately for newly granted options, unexercisable options, and exercisable options. We then divide it by total annual compensation to remove the size effect.

To test H1a, we estimate the regression (1) to examine how CFO promotion-based incentives affect accruals management:

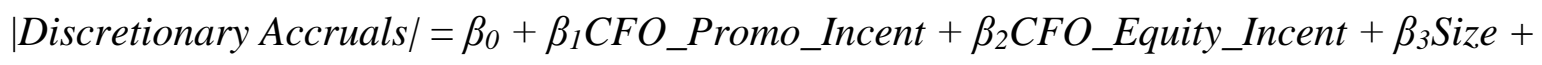

$$
\beta_{4} \text { StdCashFlow }+\beta_{5} \text { StdRev }+\beta_{6} \text { StdSalesGrowth }+\beta_{7} \text { Oldfirm }+\beta_{8} \text { Leverage }+
$$$$
\text { MarketToBookDecile }+ \text { G_index }+ \text { Year }+ \text { Exchange }+ \text { Industry }+\varepsilon
$$ 
We use the modified Jones model to measure discretionary accruals. ${ }^{8}$ We follow Bergstresser and Philippon (2006) and Jiang et al. (2010) to use the absolute value of discretionary accruals $(\mid$ Discretionary Accruals $\mid)$ as dependent variable ${ }^{9}$ to capture managerial incentives to smooth earnings and control for firm size (Size), the standard deviation of cash flows from operations (StdCashFlow), the standard deviation of revenues (StdRev), the standard deviation of sales growth (StdSalesGrowth), firm age (Oldfirm), leverage (Leverage), deciles of the market to book ratio (MarketToBookDecile), governance score (G_Index), year indicators (Year), exchange indicators (Exchange), and industry indicators (Industry). We also use signed discretionary accruals to capture CFOs' incentives to report better financial performance. Appendix A presents a description of all these variables.

To test $\boldsymbol{H} \mathbf{l b}$, we estimate the following model (2) to examine whether CFO promotionbased incentives affect the probability of meeting or beating analysts' forecasts:

Prob $($ positive surprise $=1)=\beta_{0}+\beta_{1} C F O \_$Promo_Incent $+\beta_{2}$ CFO_Equity_Incent $+\beta_{3}$ Size + $\beta_{4}$ Growth $+\beta_{5}$ SalesGrowth $+\beta_{6} \mathrm{NOA}+\beta_{7}$ Shares $+\beta_{8}$ Litigation $+\beta_{9}$ ImplicitClaims + $\beta_{10}$ AnalystFollowing $+\beta_{11}$ ForecastDispersion + Year $+\varepsilon$

Following Jiang et al. (2010), positive surprise is a dummy variable which takes the value of 1 if a firm's actual annual earnings per share reported in $\mathrm{I} / \mathrm{B} / \mathrm{E} / \mathrm{S}$ is greater than or equal to the latest analyst consensus earnings forecast from the $\mathrm{I} / \mathrm{B} / \mathrm{E} / \mathrm{S}$ summary file, and 0 otherwise. We follow Cheng and Warfield (2005) to control for firm size (Size), growth option (Growth), sales growth (SalesGrowth), net operating assets (NOA), shares outstanding (Shares), litigation risk (Litigation), implicit claims (ImplicitClaims), numbers of analysts following (AnalystFollowing), the dispersion of the consensus forecasts (ForecastDispersion), and year indicators (Year). 
To test $\boldsymbol{H 1 c}$, we estimate the following conditional logistic regression (3) to examine how CFO promotion-based incentives affect the likelihood of accounting misconduct ${ }^{10}$ :

$$
\begin{gathered}
\operatorname{Prob}(\text { Misconduct }=1)=\beta_{0}+\beta_{1} C F O \_ \text {Promo_Incent }+\beta_{2} C F O \_ \text {Equity_Incent }+\beta_{3} \Delta \text { Cash_Sales } \\
+\beta_{4} \Delta \text { Earnings }+\beta_{5} \Delta \text { Inventory }+\beta_{6} \Delta \text { Receivables }+\beta_{7} \text { Rsst_Accruals }+\varepsilon
\end{gathered}
$$

Misconduct is a dummy variable that equals 1 if the firm is charged by the SEC for accounting misconduct, and 0 otherwise. Following Feng et al. (2011), we control for the change

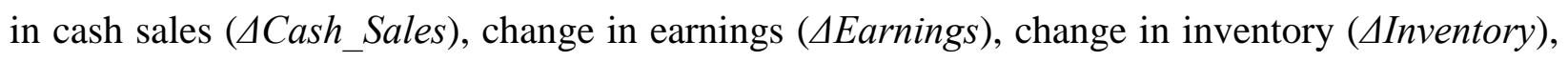
change in receivables (AReceivables), and accruals (Rsst_Accruals).

To test $\boldsymbol{H} 2$, we examine whether promotion-based incentives are associated with real earnings management by estimating regression (4):

$$
\begin{gathered}
\mid R M \_ \text {Proxy } \mid=\beta_{0}+\beta_{1} \text { CFO_PromoIncent }+\beta_{2} C F C_{-} \text {Equity_Incent }+\beta_{3} \text { Size }+\beta_{4} \text { StdCashFlow }+ \\
\beta_{5} \text { StdRev }+\beta_{6} \text { StdSalesGrowth }+\beta_{7} \text { Oldfirm }+\beta_{8} \text { Leverage }+ \text { MarketToBookDecile }+ \text { Year } \\
+G_{-} \text {index }+ \text { Exchange }+ \text { Industry }+\varepsilon
\end{gathered}
$$

Following Roychowdhury (2006), we estimate abnormal cash flows (RM_CFO), abnormal production costs (RM_Prod), and abnormal discretionary expenses $\left(R M \_D i s c E x p\right) .{ }^{11}$ We then follow Cohen et al. (2008) to construct an aggregate variable (RM_Proxy) combining the three individual real earnings management variables. Specifically, RM_Proxy is the sum of the three standardized real earnings management variables (RM_CFO, RM_Prod, and RM_DiscExp). Prior literature provides empirical evidence that CEO incentives affect their firms' earnings management (Bergstresser and Phillippon, 2006; Cheng and Warfield, 2005; Burns and Kedia, 2006). Feng et al. (2011) find that CEOs who engage in material accounting manipulations are 
more likely to be powerful CEOs. Therefore, we also control for CEO equity incentives (CEO_Equity_Incent), and CEO power, measured by CEO Pay Slice (CEO_Payslice) and CEO and Chairman-duality (CEO_Chair) in all our tests. ${ }^{12}$

\section{DATA AND RESULTS}

\subsection{Data}

The initial sample consists of all ExecuComp firms during the period 1993-2018. We identify CFOs using the data item 'titleann' in ExecuComp. We first identify any of the following phrases: CFO, chief financial officer, chief finance officer, chief accounting officer, treasurer, controller, vice president-finance, and VP-finance. If more than one person are identified as CFO, for example, one person with the title of 'CFO' and another person with the title of 'treasurer', for the same firm in the same fiscal year, we take the person with the title 'CFO'. There are a total of 50,237 firm-years with compensation data available during the test period. We delete 8,189 observations with missing CEO or CFO. We also delete 2,530 firm-year observations with a negative pay gap following Kini and Williams (2012). ${ }^{13}$ We remove firms in the financial sector (with SIC between 6000 and 6999) and lose observations when combining Compustat with I/B/E/S

and AAERs ${ }^{14}$ databases respectively. There are 28,476 firm-year observations in the final sample for the model (1), 19,483 firm-year observations for the model (2), and 25,573 for the model (4).

Following Dechow, Ge, Larson, and Sloan (2011), we use Accounting and Auditing Enforcement Releases (AAERs) to proxy for accounting misconduct. We delete firms that were charged for misconduct other than accounting manipulations (e.g., bribery, auditor issue, false press release, help other companies misstate financial statements, etc.). We exclude the observations without CIK, date, financial data, or compensation data, resulting in a sample of 267 
manipulations firms. We match each manipulation firm with two firms in the same industry, year, and with the closest beginning total assets. Our final sample for the model (3) consists of 800 firmyear observations from 1993 to 2011.

Table 1 presents descriptive statistics for the samples used in our analysis. CFO_Promo_Incent, which is the natural logarithm of the total pay gap between the CEO and the CFO, has a mean of 7.463 and a median of $7.556 .{ }^{15}$ The average CFO equity incentives and CEO equity incentives are 0.085 and 0.200 , respectively. The equity incentives (delta) statistics are comparable to those of Jiang et al. (2010) and Bergstresser and Philippon (2006). ${ }^{16}$ Among the top five executives reported in the Execucomp database ${ }^{17}$, CEO pay slice is approximately $39.4 \%$. On average, CEOs are also the Chairman of the Board of Directors in 55.8\% of firm-year observations. The mean for the absolute value of discretionary accruals (|Discretionary Accruals $\mid$ ) is 0.048 . Approximately $71 \%$ of our sample firms have their annual reported earnings meeting or beating

analysts' consensus forecasts during the test period. The mean of Misconduct, which equals 1 if the firm is charged by the SEC for accounting manipulations and 0 otherwise, is 0.334 for our matched sample used for accounting misconduct analysis. As to the main variables for the real earnings management test, the means of $R M \_C F O, R M \_P r o d$, and RM_DisExp are -0.097, -0,111, and -0.031 respectively. The mean of RM_Proxy, which is the standardized sum of the three real earnings management proxies $\left(R M \_C F O, R M \_P r o d\right.$, and $\left.R M \_D i s c E x p\right)$, is -0.037 .

[Insert Table 1]

\subsection{Accruals Management Analysis}

Panel A of Table 2 presents the Pearson correlations among the variables used in our accruals management analysis. CFO promotion-based incentives (CFO_Promo_Incent) and CFO equity incentives (CFO_Equity_Incent) are positively correlated with a coefficient of 0.215 , 
suggesting that these measures are related but capture different aspects of CFO incentives. CFO equity incentives (CFO_Equity_Incent) and CEO equity incentives (CEO_Equity_Incent) are highly correlated with a coefficient of 0.522 , indicating that the equity incentives of the CEO and the CFO are aligned. $\mid$ Discretionary Accruals $\mid$ are negatively correlated with CFO_Promo_Incent and are positively correlated with CEO_Equity_Incent, but are not correlated with CFO_Equity_Incent. Since the correlation analysis only considers the correlation between the dependent (|Discretionary Accruals $\mid$ ) and independent variable (CFO_Promo_Incent) without controlling for the effects of other independent variables, we focus on the results of multivariate analysis. $^{18}$

Panel B of Table 2 reports the ordinary least square regression results of estimating equation (1). Cohen et al. (2008) suggest that firms may switch from accrual-based earnings management to real earnings management after the Sarbanes-Oxley Act (2002). As such, we follow Jiang et al. (2010) and partition our sample into two time periods with the pre-SOX period starting from 1993 to 2001 and the post-SOX period starting from 2002 to 2018 and estimate equation (1) separately. The results for the pre-SOX period are reported in columns (1) to (4) and the results for the post-SOX period are reported in columns (5) to (8). In column (1), we only include CFO_Equity_Incent and we find that the coefficient on CFO_Equity_Incent is significantly positive (coefficient $=0.018, \mathrm{p}=0.05$ ), which is consistent with prior research that CFO equity incentives are positively associated with accruals management (Jiang et al. 2010). The coefficients on other control variables are all significant at conventional levels and in the predicted directions. We then test whether CFO promotion-based incentives affect discretionary accruals. In column (2), we find that the coefficient on CFO_Promo_Incent is significantly positive (coefficient $=0.003, \mathrm{p}<0.01)$, suggesting that $\mathrm{CFO}$ promotion-based incentives are positively 
associated with accruals management. Column (3) reports the results when both CFO_Promo_Incent and CFO_Equity_Incent are included. We find that the coefficients on both CFO_Promo_Incent $($ coefficient $=0.003, \mathrm{p}<0.01)$ and $C F O \_E q u i t y \_I n c e n t ~($ coefficient $=0.015$, $\mathrm{p}=0.09)$ continue to be significantly positive. Column (4) shows that CFO_Promo_Incent continues to be positive and significant although CFO_Equity_Incent is no longer significant after controlling for CEO equity incentives, CEO pay slice, and CEO-Chairman duality. In fact, we find that $C E O \_E q u i t y \_I n c e n t($ coefficient $=0.011, \mathrm{p}=0.02)$ subsumes $C F O \_E q u i t y \_I n c e n t$ in the preSOX period.

In the post-SOX period, we observe that the coefficient on CFO_Promo_Incent is significantly positive in column (8) only (coefficient $=0.001, \mathrm{p}=0.06)$. However, the coefficients on CFO_Equity_Incent and CEO_Equity_Incent are insignificant in column (8). We find weak results for the post-SOX period. One possible explanation is that CEOs and CFOs become more conservative since the SOX Section 302 requires CEOs and CFOs to take personal responsibility for their firms' financial reporting.

[Insert Table 2]

The absolute value of discretionary accruals is used to capture earnings smoothness, assuming that boards of directors expect CFOs to deliver more consistent accounting performance. However, it is also likely that CFOs are expected to deliver better accounting performance. As a result, we should observe a significant positive relation between signed discretionary accruals and CFO promotion-based incentives. Untabulated results show that signed discretionary accruals are not associated with CFOs' promotion-based incentives, suggesting that CFOs do not necessarily engage in earnings management through income-increasing accruals to increase their chance to get promoted to the CEO. 


\subsection{Meeting or Beating Analysts' Forecasts}

Panel A of Table 3 exhibits the Pearson correlations among the variables used in our logistic analysis of meeting or beating analysts' forecasts. Positive Surprise is positively correlated with $C F O \_P r o m o \_I n c e n t$ and $C F O \_E q u i t y \_I n c e n t$, suggesting that both CFO promotion-based incentives and CFO equity incentives are positively correlated with the likelihood of meeting or beating analysts' forecasts.

Panel B of Table 3 reports the effect of CFO promotion-based incentives on the likelihood of meeting or beating analysts' forecasts. Column (1) shows that the coefficient on CFO_Equity_Incent $($ coefficient $=1.394, \mathrm{p}<0.01)$ is significantly positive, which is consistent with Jiang et al. (2010)'s findings that CFO equity incentives are positively associated with meeting or beating analysts' forecasts. In column (2), the coefficient on CFO_Promo_Incent (coefficient $=0.167, \mathrm{p}<0.01)$ is significantly positive. We also observe that the coefficient on CFO_Promo_Incent is significantly positive in columns (3) and (4).

In the post-SOX period, the coefficients on both CFO_Promo_Incent and CFO_Equity_Incent are significantly positive. Taken together, we observe that CFO promotionbased incentives are positively associated with the likelihood of meeting or beating analysts' forecasts in both pre- and post-SOX periods, suggesting that CFOs have more incentives to avoid negative forecast surprises when they have higher promotion-based incentives.

[Insert Table 3]

\subsection{Accounting Misconduct}

Panel A of Table 4 displays the Pearson correlations for the variables used in the accounting misconduct test. We find that CFO_Promo_Incent is positively correlated with Misconduct, 
indicating CFO promotion-based incentives are positively correlated with the likelihood of accounting manipulations.

Panel B of Table 4 shows the relation between CFO promotion-based incentives and the likelihood of accounting misconduct. In the pre-SOX period, the coefficient on CFO_Promo_Incent is significantly positive in column (2) (3) and (4), indicating that the likelihood of accounting misconduct is higher when CFO promotion-based incentives increase. This finding indicates that the promotion-based incentives may have induced CFOs to commit accounting frauds. However, Misconduct is not related to CFO_Promo_Incent in the post-SOX period, suggesting that the SOX may have deterred accounting misconduct caused by CFOs' promotion incentives because CEOs and CFOs are now personally responsible for firms' financial reporting frauds in the post-SOX period (Cohen et al. 2008). We also find CEO_Equity_Incent, CFO_Equity_Incent, and CEO power measures are mostly insignificant in both pre- and postSOX periods.

[Insert Table 4]

In sum, we find consistent evidence that $\mathrm{CFO}$ promotion-based incentives are associated with opportunistic reporting activities in the pre-SOX period, while we only observe a positive association between CFO promotion-based incentives and the likelihood of meeting or beating analysts' forecasts in the post-SOX period. Our findings confirm that the SOX successfully mitigate accounting manipulations.

\subsection{Real Earnings Management}

Panel A of Table 5 presents the Pearson correlations among the variables used for the real earnings management test. CFO_Promo_Incent is negatively correlated with RM_Proxy and RM_CFO but is not correlated with $R M \_D i s c E x p$ or RM_Prod. 
Panel B of Table 5 presents the effect of CFO promotion-based incentives on real earnings management. In both pre-SOX and post-SOX periods, the coefficient on CFO_Promo_Incent is significantly negative, indicating that $\mathrm{CFO}$ promotion-based incentives mitigate real earnings management activities. The results are different from accruals management, which could be caused by the fact that real earnings management is costly in the sense that it negatively affects firms' long-run performance (e.g., Roychowdhury, 2006). If a CFO has the potential to get promoted to the CEO position, she or he should care about the firm's future performance after taking office. Furthermore, unlike accruals management that is determined and undertaken by CFOs (Jiang et al., 2010), real earnings management requires cooperation from other VPs who may be competing with CFOs for the CEO position. The coefficients on CFO_Equity_Incent and CEO_Equity_Incent are insignificant in columns (4) and (8).

\section{[Insert Table 5]}

\subsection{Cross-sectional Analyses}

If VPs including CFOs have inside information about potential CEO turnovers and plan ahead accordingly, we expect that CFO promotion-based incentives are higher in the years before CEO turnovers. ${ }^{19}$ CEO_Turnover is defined as a dummy variable that equals 1 if the test period is within two years prior to CEO turnovers, and 0 otherwise. ${ }^{20}$ Table 6 Panel A shows that in the preSOX period, the absolute value of discretionary accruals remains positively associated with CFO_Promo_Incent $($ coefficient $=0.005, \mathrm{p}<0.01)$ but negatively associated with $C E O \_T u r n o v e r$ (coefficient $=-0.015, \mathrm{p}=0.08)$. More importantly, the coefficient on the interaction term CEO_Turnover $\times$ CFO_Promo_Incent is positive and statistically significant $($ coefficient $=0.003$, $\mathrm{p}=0.03$ ), suggesting that the positive association between absolute discretionary accruals and CFO promotion incentives is more pronounced two years preceding CEO turnovers. However, the 
coefficient on the interaction term is insignificant in the post-SOX period. In Table 6 Panel B, in the pre-SOX period, the likelihood of meeting or beating analysts' forecasts remains positively associated with $C F O \_$Promo_Incent (coefficient $=0.180, \mathrm{p}<0.01$ ). The coefficient on the interaction term CEO_Turnover $\times$ CFO_Promo_Incent is positive and statistically significant (coefficient $=0.149, \mathrm{p}=0.06$ ), suggesting that the positive association between the likelihood of meeting or beating analysts' forecasts and CFO promotion incentives is also more pronounced two years preceding CEO turnovers. However, we fail to find that the interaction term is associated with Misconduct in Table 6 Panel C. Overall, we find some evidence supporting that the relation between CFO promotion-based incentives and opportunistic financial reporting is stronger when approaching CEO turnovers.

We also examine the impact of the pay gap between the CFO and other VPs (CFO_VP_ratio) in Table 6. CFO_VP_ratio is calculated as the CFO pay divided by the average pay of other VPs. Hence, a higher $C F O_{-} V P \_r a t i o$ ratio indicates that the CFO receives higher pay relative to other VPs, which may imply a higher probability of CFO being promoted to the CEO position when competing with other VPs. We, therefore, expect that $C F O \_V P \_r a t i o$ is positively associated with opportunistic financial reporting. We find that $C F O \_V P \_r a t i o$ is indeed positively associated with the absolute value of discretionary accruals in the post-SOX period $($ coefficient $=$ 0.003, $\mathrm{p}<0.01)$ in Panel A, and positively associated with meeting or beating analysts' forecasts in both pre- and Post- SOX periods (coefficient $=0.330, \mathrm{p}<0.01$ and coefficient $=0.202, \mathrm{p}<0.01$, respectively) in Panel B. We, however, do not find a significant association between $C F O \_V P \_r a t i o$ and accounting misconduct in Panels $C .{ }^{21}$ Overall, we find some evidence that CFOs engage in more opportunistic financial reporting when the pay gap between the CFO and other VPs is greater. 
Table 6 Panel D reports results for real earnings management. We do not find a significant association between the interaction term CEO_Turnover $\times$ CFO_Promo_Incent and RM_Proxy. In addition, we do not find a significant association between $C F O \_V P \_r a t i o$ and real earnings management.

[Insert Table 6]

\section{CONCLUSIONS}

This study examines whether CFO promotion-based incentives, measured by the pay gap between the $\mathrm{CEO}$ and the $\mathrm{CFO}$, affect managerial opportunistic reporting activities. Using data during 1993-2018, we provide evidence that CFO promotion-based incentives are positively associated with accruals management and accounting misconduct in the pre-SOX period. We also find that CFO promotion-based incentives are positively associated with the likelihood of meeting or beating analysts' forecasts in both pre-SOX and post-SOX periods. In addition, we document that $\mathrm{CFO}$ promotion-based incentives are negatively associated with real earnings management in both pre- and post- SOX periods. Our results are robust after controlling for CFO and CEO equity incentives and $\mathrm{CEO}$ power. Our results suggest that $\mathrm{CFO}$ promotion-based incentives may encourage CFOs to engage in more aggressive financial reporting activities but mitigate real earnings management. Moreover, we find some evidence that the association between CFO promotion-based incentives and opportunistic reporting activities is more profound before CEO turnovers. Our results also provide some support that CFOs engage in more opportunistic financial reporting when the pay gap between the CFO and other VPs is greater. The findings of this study should be of interest to boards of directors, regulators, and academics. 
Our study is not without caveats. We are unable to determine whether corporate boards will attribute the inflated firm performance solely to CFOs. Hence, earnings management driven by CFO promotion-based incentives may help CEOs secure their positions. We argue that this concern may not discourage CFOs to manage earnings in order to outperform other VPs because the Boards of Directors are likely to consider the CEO successor based on the various criterion and relative performance benchmarks (e.g., Lazear, 1989; Gibbs, 1995). Future research can further examine how VPs including the CFO impress corporate boards with their abilities and help the boards differentiate their performance from the CEO. 


\section{REFERENCES}

Aggarwal, R., and A. Samwick. 2003. Performance incentives within firms: the effect of managerial responsibility. Journal of Finance 58: 1613-1649.

Bebchuk, L., M. Creamers, and U. Peyer. 2011. The CEO pay slice. Journal of Financial Economics 102: 199-221.

Bergstresser, D., and T. Philippon. 2006. CEO incentives and earnings management. Journal of Financial Economics 80: 511-529.

Bognanno, M.L. 2001. Corporate tournaments. Journal of Labor Economics 19: 290-315.

Burns, N., and S. Kedia. 2006. The impact of equity compensation on misreporting. Journal of Financial Economics 79 (1): 35-67.

Chava, S., and A. Purnanandam. 2010. CEOs versus CFOs: incentives and corporate policies. Journal of Financial Economics 97: 263-278.

Cheng, Q., and T. Warfield. 2005. Equity incentives and earnings management. The Accounting Review 80: 441-476.

Cohen, D., A. Dey, and T. Lys. 2008. Real and accruals-based earnings management in the preand post-Sarbanes Oxley periods. The Accounting Review 83: 757-787.

Core, J., and W. Guay. 2002. Estimating the value of employee stock option portfolios and their sensitivities to price and volatility. Journal of Accounting Research 40: 613-630.

Dechow, P. M., W. Ge, C. R. Larson, and R. G. Sloan. 2011. Predicting Material Accounting Misstatements. Contemporary Accounting Research 28 (1): 17-82.

Duellman, S., A. S. Ahmed, and A. M. Abdel-Meguid. 2013. An empirical analysis of the effects of monitoring intensity on the relation between equity incentives and earnings management. Journal of Accounting and Public Policy (32): 495-517.

Falk, R. F., and N. B. Miller. 1992. A primer for soft modeling. University of Akron Press.

Fama, E., and K. French. 1997. Industry costs of equity. Journal of Financial Economics 43, 153-193.

Feng, M., W. Ge, S. Luo, and T. Shevlin. 2011. Why do CFOs become involved in material accounting manipulations? Journal of Accounting and Economics 51: 21-36.

Ge, W., D. Matsumoto, and J.L. Zhang. 2010. Do CFOs have styles? An empirical investigation of the effect of individual CFOs on accounting practices. Contemporary Accounting Research 28 (4): 1141-1179.

Geiger, M., and D. North. 2006. Does hiring a new CFO change things? An investigation of changes in discretionary accruals. The Accounting Review 81: 781-809.

Gibbs, M.. 1995. Incentive compensation in a corporate hierarchy. Journal of Accounting and Economics 19 (2-3): 247-277. 
Gompers, P., J. Ishii, and A. Metrick. 2003. Corporate governance and equity prices. Quarterly Journal of Economics 118: 107-155.

Green, J. R., and N. L. Stokey. 1983. A comparison of tournaments and contracts. Journal of Political Economy 91: 349-364.

Henderson, A.D., and J. W. Fredrickson. 2001. Top management team coordination needs and the CEO pay gap: a competitive test of economic and behavioral views. Academy Management Journal 44 (1): 96-117.

Jiang, X., K.R. Petroni, and I. Y. Wang. 2010. CFOs versus CEOs: who has the most influence on earnings management? Journal of Financial Economics 96: 513-526.

Kale, J.R., E. Reis, and A. Venkateswaran. 2009. Rank-order tournaments and incentive alignment: the effect on firm performance. Journal of Finance 64: 1479-1512.

Kini, O., and R. Williams. 2012. Tournament incentives, firm risk, and corporate policies. Journal of Financial Economics 103: 350-376.

Lazear, E.P.. 1989. Pay equality and industrial politics. Journal of Political Economy 97 (3): $561-$ 580.

Lazear, E. P., and S. Rosen. 1981. Rank order tournaments as an optimum labor contract. Journal of Political Economy 89: 841-64.

Mian, S., 2001. On the choice and replacement of chief financial officers. Journal of Financial Economics 60: 143-175.

Murphy, K. J., and J. L. Zimmerman. 1993. Financial Performance Surrounding CEO Turnover. Journal of Accounting and Economics: 16 (1):273-315.

Park, K. E.. 2017. Pay disparities within top management teams and earning management. Journal of Accounting and Public Policy 36 (1): 59-81.

Prendergast, C. 1999. The provision of incentives in firms. Journal of Economic Literature 37: 7-63.

Roychowdhury, S. 2006. Earnings management through real activities manipulations. Journal of Accounting and Economics 42(3), 335-370.

Vo, T. T. N., and J.M. Canil. 2019. CEO pay disparity: Efficient contracting or managerial power? Journal of Corporate Finance 54: 168-190. 


\section{FOOTNOTES}

\footnotetext{
${ }^{1}$ Prior studies use the term tournament incentives (eg. Kini and Williams, 2012), while we use the term promotionbased incentives in this study.

${ }^{2}$ We do not argue that all CFOs are equipped with all these abilities, but an increasingly competitive global environment, like the one we are in now, does require CFOs to be able to handle most of the functions that are currently dealt with by CEOs.
}

3 The sample period for our accounting misconduct analysis is from 1993 to 2011.

4 It is defined as whether CEOs or CFOs were included in the SEC's Accounting and Auditing Enforcement Releases.

${ }^{5}$ They follow Aggarwal and Samwick (2003) to define both CEO and CFO equity incentives as (Number of shares held by the $\mathrm{CEO}$ or $\mathrm{CFO}+$ delta of options $\times$ number of options held by the $\mathrm{CEO}$ or $\mathrm{CFO}$ )/ total number of shares outstanding $\times 100$.

${ }^{6}$ Firm focus is computed as the segment sales-based Herfindahl index. It is equal to one if the firm operates solely in one segment, and decreases as the firm diversifies.

${ }^{7}$ Park (2017) focuses on the association between the CEO_VPs pay gap and real earnings management and decompose the pay gap into CFO and non-CFO VPs as an additional test. The author observes a negative association between real earnings management and the long-term pay gap between the CEO and the CFO, although the author fails to observe any significant association between the short-term pay gap between the CEO and the CFO and real earnings management.

${ }^{8}$ We use the modified Jones model below to estimate both non-discretionary accruals and discretionary accruals. $A C C_{\text {icoef. }}=\beta_{0}+\beta_{1}\left(1 / T A_{t-1}\right)+\beta_{2}\left(\Delta\right.$ Sales $\left._{i t}-\Delta \operatorname{Rec}_{i t}\right)+\beta_{3}\left(P P E_{i t}\right)+\varepsilon_{t}$, where $A C C_{i t}$ is accruals deflated by beginning total assets. $T A_{t-I}$ is beginning total assets, $\triangle$ Sales $_{i t}$ is the change in sales deflated by beginning total assets, $\triangle R e c_{i t}$ is the change in accounts receivable deflated by beginning total assets. $P P E_{i t}$ is gross property, plant, and equipment deflated by beginning total assets. $\beta_{0}, \beta_{1}, \beta_{2}$, and $\beta_{3}$ are estimated cross-sectionally for each year and industry combination. We estimate non-discretionary accruals deflated by beginning total assets $\left(N D A C C_{i t}\right)$ based on these cross-sectional coefficients along with each firm's data. Discretionary accruals deflated by beginning total assets $\left(D A C C_{i t}\right)$ are therefore $A C C_{i t}$ less $N D A C C_{i t}$.

${ }^{9} \mathrm{We}$ use the absolute value of discretionary accruals to be consistent with previous studies (e.g., Bergstresser and Philippon, 2006; Jiang et al., 2010) and allow us to compare our results with previous studies with similar dependent variables and control variables. Our results using absolute values of abnormal accruals are generally consistent with the literature and our prediction. We also believe that to some extent, absolute values of discretionary accruals include discretionary accruals reversal. It is also likely that CFOs have considered discretionary accruals reversal when determining the magnitude of earnings management.

${ }^{10}$ Conditional logistic regression allows for stratification and matching. It's used since the sample consist of fraud firms and control firms matched using company size, and the choice of the regression is consistent with Feng et al. (2011). Our results using regular logistic regression are consistent.

11 To estimate $R M_{-} C F O$, we run the following cross-sectional model by every industry and year to get the residual: $C F O_{t} / A_{t-1}=\beta_{0}+\beta_{I}\left(1 / A_{t-1}\right)+\beta_{2}\left(S_{t} / A_{t-1}\right)+\beta_{3}\left(\Delta S_{t} / A_{t-1}\right)+\varepsilon_{t}$, where $C F O_{t}$ is the cash flow, $A_{t-1}$ is the beginning total assets, $S_{t}$ is the sales, and $\Delta S_{\text {coef. }}=S_{t}-S_{t-1}$.

To estimate $R M_{-}$Prod, we first run the following cross-sectional model by every industry and year to get the residual: $\left.\left.\operatorname{Prod}_{t} / A_{t-1}=\beta_{0}+\beta_{1}\left(1 / A_{t-1}\right)+\beta_{2}\left(S_{t} / A_{t-1}\right)\right)+\beta_{3}\left(\Delta S_{t} / A_{t-1}\right)\right)+\beta_{4}\left(\Delta S_{t-1} / A_{t-1}\right)+\varepsilon_{t}$, where $\operatorname{Prod}_{t}$ is the sum of COGS and inventory growth.

To estimate RM_DiscExp, we first run the following cross-sectional model by every industry and year to get the residual: DiscExpt/At $\left.A_{t-1}=\beta_{0}+\beta_{1}\left(1 / A_{t-1}\right)+\beta_{2}\left(S_{t-1} / A_{t-1}\right)\right)+\varepsilon_{t}$, where DiscExp ${ }_{t}$ is the discretionary expenses.

${ }^{12}$ Controlling for CEO pay slice also addresses another concern that the pay gap between the CEOs and CFOs may capture the agency problem of CEOs. Bebchuk, Creamers, and Peyer (2011) argue that CEO pay slice may reflect CEOs' ability to extract rents. 
${ }^{13}$ They find that a negative pay gap occurred in the companies with the CEO being the founder or receiving nominal compensation, which is not a good proxy for promotion-based incentives.

${ }^{14}$ According to the SEC, this public database includes financial reporting related enforcement actions concerning civil lawsuits brought by the SEC in federal court and notices and orders concerning the institution and/or settlement of administrative proceedings. For details, please refer to https://www.sec.gov/divisions/enforce/friactions.shtml.

${ }^{15}$ For our sample, the average and median CEO and CFO pay gap are $\$ 3,640,000$ and $\$ 1,911,000$, respectively.

${ }^{16}$ Jiang et al. (2010) document that CEOs' and CFOs' average equity incentives during the sample period (19932006) are 0.236 and 0.105, respectively. Bergstresser and Philippon (2006) report average CEO equity incentives of 0.244 for the period 1993-2000.

${ }^{17}$ If Execucomp database discloses more than five executives, we only consider the five highest-paid executives. If Execucomp discloses less than five executives, we assume the undisclosed executives receive the same pay as the lowest-paid executive disclosed.

${ }^{18}$ |Discretionary Accruals| are negatively correlated with CFO_Promo_Incent, however, in our multivariate

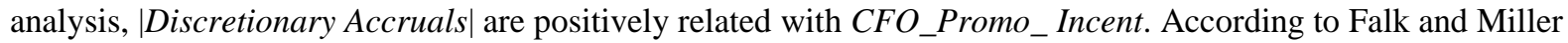
(1992), when the regression coefficient and the correlation don't have the same sign, one of the reasons is real suppression, which means an important independent variable suppresses the effect of another independent variable.

${ }^{19}$ It is reasonable to assume that CFOs and other VPs have internal information advantages and can foresee CEO turnover. This is because CFOs and other VPs are top managers who work with the Board of Directors regularly and should have inside information to foresee CEO turnover.

${ }^{20}$ We follow Murphy and Zimmerman (1993) to use two years preceding CEO turnover as the cutoff.

${ }^{21}$ We also examine whether firms' internal promotion history affects the association between the CEO_CFO pay gap and opportunistic reporting behavior. We predict that CFOs in firms with incumbent CEOs who are hired within the firm may have higher promotion-based incentives to manage earnings. However, the untabulated result does not support our prediction. 


\section{Appendix A - Variable Definitions}

\begin{tabular}{|c|c|}
\hline Variable Name & Description \\
\hline CFO_Promo_Incent & The logarithm of the total pay gap between the CEO and the CFO; \\
\hline CFO_Equity_Incent & CFO's equity incentive ratio per Bergstresser and Philippon(2006); \\
\hline CEO_Equity_Incent & CEO's equity incentive ratio per Bergstresser and Philippon(2006); \\
\hline CEO_Payslice & CEO pay divided by the sum of the pay of top 5 senior executives; \\
\hline CEO_Chair & $\begin{array}{l}\text { A dummy variable that equals } 1 \text { if the CEO is also Chairman of the Board, } \\
\text { and } 0 \text { otherwise; }\end{array}$ \\
\hline |Discretionary & The absolute value of abnormal accruals estimated by using the Modified \\
\hline Accruals & Jones Model; \\
\hline Size & The natural logarithm of lagged total assets; \\
\hline OldFirm & $\begin{array}{l}\text { A dummy variable that equals } 1 \text { if a firm is included in Compustat for more } \\
\text { than } 20 \text { years, and } 0 \text { otherwise; }\end{array}$ \\
\hline StdSalesGrowth & $\begin{array}{l}\text { The standard deviation of sales growth over the current and previous four } \\
\text { years; }\end{array}$ \\
\hline Leverage & Total liabilities deflated by total assets; \\
\hline StdRev & $\begin{array}{l}\text { The standard deviation of sales deflated by total assets over the current and } \\
\text { previous four years; }\end{array}$ \\
\hline StdCashFlow & $\begin{array}{l}\text { The standard deviation of sales growth over the current and previous four } \\
\text { years; }\end{array}$ \\
\hline MarketToBookDecile & $\begin{array}{l}\text { The indicators of market value to book value deciles, which are calculated as } \\
\text { deciles of the market value of assets divided by the book value of assets, } \\
\text { ranked within each year; }\end{array}$ \\
\hline Positive surprise & $\begin{array}{l}\text { A dummy variable that equals } 1 \text { if a firm's actual earnings per share is greater } \\
\text { or equal to the latest analyst consensus forecast, and } 0 \text { otherwise; }\end{array}$ \\
\hline Growth & The book value of equity to market value of equity at the beginning of year $t$; \\
\hline SalesGrowth & The sales in year $\mathrm{t}$ divided by sales in year $\mathrm{t}-1$; \\
\hline NOA & The net operating assets deflated by sales measured at the beginning of year $t$; \\
\hline Shares & $\begin{array}{l}\text { The natural logarithm of common shares outstanding measured at the end of } \\
\text { year t; }\end{array}$ \\
\hline Litigation & $\begin{array}{l}\text { A dummy variable that equals } 1 \text { if the firm is in the following industries: } \\
\text { pharmaceutical, biotechnology, computer, electronics, or retail, and } 0 \\
\text { otherwise; }\end{array}$ \\
\hline ImplicitClaims & 1 minus the ratio of gross PPE to total assets measured at the end of year $t$; \\
\hline AnalystFollowing & $\begin{array}{l}\text { The number of analysts whose forecasts are included in the } \mathrm{I} / \mathrm{B} / \mathrm{E} / \mathrm{S} \text { consensus } \\
\text { annual earnings forecast; }\end{array}$ \\
\hline ForecastDispersion & $\begin{array}{l}\text { The coefficient of variation of the consensus forecast(standard deviation } \\
\text { divided by the mean of analysts' forecasts); }\end{array}$ \\
\hline Year & The year indicators; \\
\hline G_Index & $\begin{array}{l}\text { Governance index per Gompers, Ishii, and Metrick ( } 2003 \text { ): } \mathrm{G} 1 \text { equals } 1 \text { if } \mathrm{G}< \\
=6 \text {, and } 0 \text { otherwise; } \mathrm{G} 2 \text { equals } 1 \text { if } 7<=\mathrm{G}<=9 \text {, and } 0 \text { otherwise; } \mathrm{G} 3 \text { equals } \\
1 \text { if } 10<=\mathrm{G}<=12 \text {, and } 0 \text { otherwise; G4 equals } 1 \text { if } \mathrm{G}>=13 \text {, and } 0 \\
\text { otherwise; }\end{array}$ \\
\hline Exchange & The exchange indicators; \\
\hline
\end{tabular}




\begin{tabular}{|c|c|}
\hline Industry & The Fama and French industry indicators; \\
\hline Misconduct & $\begin{array}{l}\text { A dummy variable that equals } 1 \text { if charged by the SEC for accounting } \\
\text { manipulations, and } 0 \text { otherwise; }\end{array}$ \\
\hline$\Delta$ Cash_Sales & $\begin{array}{l}\text { The rate of change in cash sales, where cash sales are sales minus change in } \\
\text { Accounts Receivable; }\end{array}$ \\
\hline$\Delta$ Earnings & The annual change in Net Income divided by average total Assets; \\
\hline Anventory & The annual change in Inventory divided by average total Assets; \\
\hline$\Delta$ Recievables & The annual change in Receivable divided by average total Assets; \\
\hline Rsst_Accruals & $\begin{array}{l}(\triangle W C+\triangle N C O+\triangle F I N) / \text { Average total assets, where } W C=[\text { Current Assets }- \\
\text { Cash and Short-term Investments }]-[\text { Current Liabilities }- \text { Debt in Current } \\
\text { Liabilities }] ; N C O=[\text { Total Assets }- \text { Current Assets }- \text { Investments and } \\
\text { Advances }]-[\text { Total Liabilities }- \text { Current Liabilities }- \text { Long-term Debt }] ; \\
F I N=[\text { Short-term Investments + Long-term Investments }]-[\text { Long-term Debt + } \\
\text { Debt in Current Liabilities + Preferred Stock }] ;\end{array}$ \\
\hline RM_Proxy & $\begin{array}{l}\text { The standardized sum of the three real earnings management proxies } \\
\left(R M \_C F O, R M \_P r o d, \text { and } R M \_D i s c E x p\right) \text {; }\end{array}$ \\
\hline CEO_Turnover & $\begin{array}{l}\text { A dummy variable that equals one if the test periods falls within the last two } \\
\text { years approaching CEO turnovers, and } 0 \text { otherwise; }\end{array}$ \\
\hline CFO_VP_Ratio & CFO pay divided by the average VP pay. \\
\hline
\end{tabular}


Table 1: Descriptive statistics

\begin{tabular}{|c|c|c|c|c|c|c|}
\hline Variables & $\mathrm{N}$ & Mean & Median & Std Dev & Lower quartile & Upper quartile \\
\hline $\mid$ Discretionary Accruals| & 28,476 & 0.048 & 0.033 & 0.049 & 0.015 & 0.063 \\
\hline CFO_Promo_Incent & 28,476 & 7.463 & 7.556 & 1.244 & 6.645 & 8.365 \\
\hline CFO_Equity_Incent & 28,476 & 0.085 & 0.053 & 0.095 & 0.022 & 0.110 \\
\hline CEO_Equity_Incent & 28,476 & 0.200 & 0.128 & 0.204 & 0.057 & 0.266 \\
\hline CEO_Chair & 28,476 & 0.558 & 1.000 & 0.497 & 0 & 1.000 \\
\hline CEO_PaySlice & 28,476 & 0.394 & 0.390 & 0.104 & 0.325 & 0.455 \\
\hline$V P \_C F O \_$Ratio & 26,832 & 1.043 & 0.983 & 0.452 & 0.767 & 1.223 \\
\hline Size & 28,476 & 7.298 & 7.196 & 1.612 & 6.120 & 8.372 \\
\hline StdCashFlow & 28,476 & 0.048 & 0.035 & 0.043 & 0.021 & 0.058 \\
\hline StdRev & 28,476 & 0.147 & 0.105 & 0.136 & 0.060 & 0.185 \\
\hline StdSalesGrowth & 28,476 & 0.206 & 0.125 & 0.281 & 0.067 & 0.229 \\
\hline Oldfirm & 28,476 & 0.569 & 1.000 & 0.495 & 0 & 1.000 \\
\hline Leverage & 28,476 & 0.531 & 0.533 & 0.229 & 0.374 & 0.673 \\
\hline Positive Surprise & 19,483 & 0.710 & 1.000 & 0.454 & 0 & 1.000 \\
\hline Size_BM & 19,483 & 7.623 & 7.506 & 1.554 & 6.475 & 8.635 \\
\hline Growth & 19,483 & 0.473 & 0.409 & 0.344 & 0.249 & 0.617 \\
\hline SalesGrowth & 19,483 & 1.222 & 1.066 & 1.147 & 0.980 & 1.169 \\
\hline$N O A$ & 19,483 & 0.808 & 0.599 & 0.709 & 0.350 & 1.000 \\
\hline Shares & 19,483 & 4.346 & 4.138 & 1.183 & 3.468 & 5.075 \\
\hline Litigation & 19,483 & 0.265 & 0 & 0.441 & 0 & 1.000 \\
\hline ImplicitClaims & 19,483 & 0.457 & 0.558 & 0.387 & 0.194 & 0.772 \\
\hline AnalystFollowing & 19,483 & 11.033 & 9.000 & 7.377 & 5.000 & 15.000 \\
\hline ForecastDispersion & 19,483 & 0.020 & 0.013 & 0.102 & 0.006 & 0.030 \\
\hline Misconduct & 800 & 0.334 & 0 & 0.472 & 0 & 1.000 \\
\hline ACash_Sale & 800 & 0.174 & 0.090 & 0.364 & -0.005 & 0.251 \\
\hline$\triangle I B$ & 800 & 0.000 & 0.006 & 0.100 & -0.022 & 0.034 \\
\hline$\Delta I n v t$ & 800 & 0.008 & 0.000 & 0.035 & -0.002 & 0.017 \\
\hline$\Delta R e c t$ & 800 & 0.014 & 0.010 & 0.051 & -0.007 & 0.038 \\
\hline Rsst_Accruals & 800 & 0.050 & 0.034 & 0.169 & -0.022 & 0.106 \\
\hline RM_Proxy & 25,573 & -0.037 & -0.022 & 0.109 & -0.057 & 0.005 \\
\hline$R M \_C F O$ & 25,573 & -0.097 & -0.065 & 0.390 & -0.164 & 0.008 \\
\hline RM_Prod & 25,573 & -0.111 & -0.068 & 0.404 & -0.199 & 0.038 \\
\hline RM_DisExp & 25,573 & -0.031 & -0.004 & 1.005 & -0.184 & 0.142 \\
\hline
\end{tabular}

Variable definitions are presented in Appendix A. 
Table 2 Panel A: Pearson correlations of main variables for the accruals management test

\begin{tabular}{|c|c|c|c|c|c|c|c|c|c|c|c|c|c|}
\hline & & $\begin{array}{c}\mid \text { Discretionary } \\
\text { Accruals } \mid\end{array}$ & $V 1$ & $V 2$ & $V 3$ & V4 & V5 & V6 & $V 7$ & $V 8$ & $V 9$ & $V 10$ & $V 11$ \\
\hline$V 1$ & CFO_Promo_Incent & -0.095 & & & & & & & & & & & \\
\hline$V 2$ & CFO_Equity_Incent & 0.006 & 0.215 & & & & & & & & & & \\
\hline$V 3$ & CEO_Equity_Incent & 0.027 & 0.141 & 0.522 & & & & & & & & & \\
\hline$V 4$ & CEO_Chair & -0.017 & 0.101 & 0.089 & 0.212 & & & & & & & & \\
\hline$V 5$ & CEO_PaySlice & -0.034 & 0.625 & 0.049 & -0.001 & 0.065 & & & & & & & \\
\hline$V 6$ & VP_CFO_Ratio & -0.001 & -0.061 & 0.066 & -0.082 & -0.052 & 0.290 & & & & & & \\
\hline$V 7$ & Size & -0.239 & 0.613 & 0.185 & 0.088 & 0.154 & 0.167 & -0.020 & & & & & \\
\hline$V 8$ & StdCashFlow & 0.295 & -0.178 & -0.055 & -0.027 & -0.095 & -0.071 & -0.018 & -0.423 & & & & \\
\hline$V 9$ & StdRev & 0.236 & -0.110 & -0.042 & -0.020 & -0.044 & -0.036 & 0.002 & -0.244 & 0.396 & & & \\
\hline V10 & StdSalesGrowth & 0.158 & -0.067 & 0.018 & 0.017 & -0.055 & -0.038 & -0.017 & -0.175 & 0.432 & 0.241 & & \\
\hline$V 11$ & Oldfirm & -0.139 & 0.152 & -0.024 & -0.103 & 0.093 & 0.073 & 0.016 & 0.356 & -0.234 & -0.159 & -0.194 & \\
\hline V12 & Leverage & -0.035 & 0.190 & -0.075 & -0.152 & 0.079 & 0.085 & 0.013 & 0.394 & -0.120 & 0.008 & -0.087 & 0.186 \\
\hline
\end{tabular}

Correlations significant at the 5\% level or less appear in bold. All variables are defined in Appendix A. 
Table 2 Panel B: OLS regression of the absolute value of discretionary accruals on the CFO promotionbased incentives

\begin{tabular}{|c|c|c|c|c|c|c|c|c|}
\hline \multirow{3}{*}{ Variables } & \multicolumn{8}{|c|}{ Dependent Variable $=\mid$ Discretionary Accruals $\mid$} \\
\hline & \multicolumn{3}{|c|}{ pre-SOX } & \multirow[b]{2}{*}{ (4) } & \multicolumn{3}{|c|}{ post-SOX } & \multirow[b]{2}{*}{$(8)$} \\
\hline & (1) & (2) & (3) & & $(5)$ & (6) & (7) & \\
\hline \multirow[t]{2}{*}{ Intercept } & 0.032 & 0.020 & 0.020 & 0.017 & 0.056 & 0.055 & 0.055 & 0.055 \\
\hline & $(0.02)$ & $(0.17)$ & $(0.17)$ & $(0.21)$ & $(<0.01)$ & $(<0.01)$ & $(<0.01)$ & $(<0.01)$ \\
\hline \multirow[t]{2}{*}{ CFO_Promo_Incent } & & 0.003 & 0.003 & 0.005 & & 0.000 & 0.000 & 0.001 \\
\hline & & $(<0.01)$ & $(<0.01)$ & $(<0.01)$ & & $(0.42)$ & $(0.41)$ & $(0.06)$ \\
\hline \multirow[t]{2}{*}{ CFO_Equity_Incent } & 0.018 & & 0.015 & 0.005 & 0.010 & & 0.010 & 0.007 \\
\hline & $(0.05)$ & & $(0.09)$ & $(0.59)$ & $(0.03)$ & & $(0.03)$ & $(0.15)$ \\
\hline \multirow[t]{2}{*}{ CEO_Equity_Incent } & & & & 0.011 & & & & 0.004 \\
\hline & & & & $(0.02)$ & & & & $(0.11)$ \\
\hline \multirow[t]{2}{*}{ CEO_Chair } & & & & 0.002 & & & & 0.001 \\
\hline & & & & $(0.14)$ & & & & $(0.40)$ \\
\hline \multirow[t]{2}{*}{ CEO_PaySlice } & & & & -0.026 & & & & -0.009 \\
\hline & & & & $(<0.01)$ & & & & $(0.06)$ \\
\hline \multirow[t]{2}{*}{ Size } & -0.004 & -0.005 & -0.006 & -0.007 & -0.004 & -0.004 & -0.004 & -0.004 \\
\hline & $(<0.01)$ & $(<0.01)$ & $(<0.01)$ & $(<0.01)$ & $(<0.01)$ & $(<0.01)$ & $(<0.01)$ & $(<0.01)$ \\
\hline \multirow[t]{2}{*}{ StdCashFlow } & 0.172 & 0.164 & 0.166 & 0.168 & 0.184 & 0.183 & 0.184 & 0.184 \\
\hline & $(<0.01)$ & $(<0.01)$ & $(<0.01)$ & $(<0.01)$ & $(<0.01)$ & $(<0.01)$ & $(<0.01)$ & $(<0.01)$ \\
\hline \multirow[t]{2}{*}{ StdRev } & 0.050 & 0.049 & 0.049 & 0.048 & 0.030 & 0.030 & 0.030 & 0.030 \\
\hline & $(<0.01)$ & $(<0.01)$ & $(<0.01)$ & $(<0.01)$ & $(<0.01)$ & $(<0.01)$ & $(<0.01)$ & $(<0.01)$ \\
\hline \multirow[t]{2}{*}{ StdSalesGrowth } & 0.005 & 0.005 & 0.005 & 0.004 & 0.004 & 0.004 & 0.004 & 0.004 \\
\hline & $(0.07)$ & $(0.09)$ & $(0.11)$ & $(0.20)$ & $(0.10)$ & $(0.10)$ & $(0.11)$ & $(0.11)$ \\
\hline \multirow[t]{2}{*}{ Oldfirm } & -0.003 & -0.003 & -0.003 & -0.002 & -0.001 & -0.001 & -0.001 & -0.001 \\
\hline & $(0.08)$ & $(0.08)$ & $(0.12)$ & $(0.18)$ & $(0.41)$ & $(0.43)$ & $(0.43)$ & $(0.50)$ \\
\hline \multirow[t]{2}{*}{ Leverage } & 0.027 & 0.026 & 0.025 & 0.025 & 0.009 & 0.009 & 0.009 & 0.009 \\
\hline & $(<0.01)$ & $(<0.01)$ & $(<0.01)$ & $(<0.01)$ & $(<0.01)$ & $(<0.01)$ & $(<0.01)$ & $(<0.01)$ \\
\hline $\mathrm{R}^{2}$ & $17.53 \%$ & $17.80 \%$ & $17.84 \%$ & $18.10 \%$ & $12.52 \%$ & $12.49 \%$ & $12.52 \%$ & $12.57 \%$ \\
\hline No. of Observations & 8,266 & 8,266 & 8,266 & 8,266 & 20,210 & 20,210 & 20,210 & 20,210 \\
\hline \multicolumn{9}{|c|}{$\begin{array}{l}\text { All variables are defined in Appendix A. The two-tailed p-values are presented in parentheses and are } \\
\text { computed using heteroskedasticity robust standard errors, clustered by firm. All continuous variables are } \\
\text { winzorized at } 1 \% \text { and } 99 \% \text { to mitigate the effect of outliers. For the sake of brevity, we do not report } \\
\text { coefficient estimates for MarketToBookDecile indicators, year indicators, exchange indicators, G index } \\
\text { dummies, and the Fama and French (1997) industry indicators. }\end{array}$} \\
\hline
\end{tabular}


Table 3 Panel A: Pearson correlations of main variables for the meeting or beating analysts' forecasts test

\begin{tabular}{|c|c|c|c|c|c|c|c|c|c|c|c|c|c|c|c|c|}
\hline & & $\begin{array}{l}\text { Positive } \\
\text { Surprise }\end{array}$ & $V 1$ & $V 2$ & $V 3$ & V4 & V5 & V6 & V7 & $V 8$ & $V 9$ & V10 & $V 11$ & $V 12$ & $V 13$ & $V 14$ \\
\hline$V 1$ & CFO_Promo_Incent & 0.086 & & & & & & & & & & & & & & \\
\hline$V 2$ & CFO_Equity_Incent & 0.072 & 0.216 & & & & & & & & & & & & & \\
\hline$V 3$ & CEO_Equity_Incent & 0.068 & 0.133 & 0.511 & & & & & & & & & & & & \\
\hline$V 4$ & CEO_Chair & 0.016 & 0.094 & 0.079 & 0.212 & & & & & & & & & & & \\
\hline V5 & CEO_PaySlice & 0.032 & 0.612 & 0.044 & -0.011 & 0.066 & & & & & & & & & & \\
\hline V6 & $V P \_C F O \_$Ratio & 0.014 & -0.072 & 0.072 & -0.088 & -0.052 & 0.289 & & & & & & & & & \\
\hline$V 7$ & Size_BM & 0.038 & 0.622 & 0.216 & 0.110 & 0.142 & 0.147 & -0.035 & & & & & & & & \\
\hline V8 & Growth & -0.053 & -0.171 & -0.233 & -0.210 & -0.016 & -0.045 & 0.028 & -0.054 & & & & & & & \\
\hline$V 9$ & SalesGrowth & 0.021 & 0.053 & 0.043 & 0.019 & 0.026 & -0.005 & -0.022 & 0.103 & -0.014 & & & & & & \\
\hline V10 & $N O A$ & -0.043 & 0.075 & 0.019 & -0.024 & 0.011 & 0.014 & 0.013 & 0.264 & 0.220 & 0.029 & & & & & \\
\hline$V 11$ & Shares & 0.063 & 0.577 & 0.229 & 0.157 & 0.080 & 0.095 & -0.058 & 0.833 & -0.169 & 0.093 & 0.168 & & & & \\
\hline$V 12$ & Litigation & 0.073 & -0.031 & 0.016 & 0.093 & -0.081 & -0.054 & -0.042 & -0.162 & -0.048 & -0.010 & -0.182 & -0.003 & & & \\
\hline$V 13$ & ImplicitClaims & 0.095 & 0.047 & 0.084 & 0.117 & -0.075 & -0.002 & 0.017 & -0.153 & -0.143 & 0.005 & -0.270 & -0.066 & 0.141 & & \\
\hline V14 & AnalystFollowing & 0.089 & 0.450 & 0.310 & 0.265 & 0.090 & 0.052 & -0.073 & 0.602 & -0.223 & 0.085 & 0.130 & 0.669 & 0.103 & -0.073 & \\
\hline$V 15$ & ForecastDispersion & -0.036 & -0.021 & -0.026 & -0.016 & 0.004 & -0.007 & 0.007 & 0.000 & 0.001 & -0.000 & 0.017 & -0.024 & -0.019 & -0.024 & -0.021 \\
\hline
\end{tabular}

Correlations are significant at the 5\% level or lower appear in bold. All variables are defined in Appendix A. 
Table 3 Panel B: Logistic analysis of the likelihood of meeting or beating analysts' forecasts on the CFO promotion-based incentives

\begin{tabular}{|c|c|c|c|c|c|c|c|c|}
\hline \multirow{3}{*}{ Variables } & \multicolumn{8}{|c|}{ Dependent Variable $=$ Positive Surprise } \\
\hline & \multicolumn{3}{|c|}{ pre-SOX } & \multirow[b]{2}{*}{ (4) } & \multicolumn{3}{|c|}{ post-SOX } & \multirow[b]{2}{*}{$(8)$} \\
\hline & $(1)$ & $(2)$ & (3) & & $(5)$ & $(6)$ & $(7)$ & \\
\hline \multirow[t]{2}{*}{ Intercept } & 0.498 & -0.154 & -0.174 & -0.256 & 0.210 & -0.366 & -0.354 & -0.366 \\
\hline & $(0.07)$ & $(0.65)$ & $(0.61)$ & $(0.47)$ & $(0.21)$ & $(0.07)$ & $(0.08)$ & $(0.07)$ \\
\hline \multirow[t]{2}{*}{ CFO_Promo_Incent } & & 0.167 & 0.156 & 0.188 & & 0.121 & 0.118 & 0.134 \\
\hline & & $(<0.01)$ & $(<0.01)$ & $(<0.01)$ & & $(<0.01)$ & $(<0.01)$ & $(<0.01)$ \\
\hline \multirow[t]{2}{*}{ CFO_Equity_Incent } & 1.394 & & 1.167 & 0.860 & 0.828 & & 0.779 & 0.611 \\
\hline & $(<0.01)$ & & $(0.03)$ & $(0.15)$ & $(<0.01)$ & & $(<0.01)$ & $(0.04)$ \\
\hline \multirow[t]{2}{*}{ CEO_Equity_Incent } & & & & 0.303 & & & & 0.158 \\
\hline & & & & $(0.21)$ & & & & $(0.25)$ \\
\hline \multirow[t]{2}{*}{ CEO_Chair } & & & & 0.020 & & & & 0.065 \\
\hline & & & & $(0.81)$ & & & & $(0.16)$ \\
\hline \multirow[t]{2}{*}{ CEO_PaySlice } & & & & -0.366 & & & & -0.224 \\
\hline & & & & $(0.46)$ & & & & $(0.46)$ \\
\hline \multirow[t]{2}{*}{ Size } & 0.086 & 0.030 & 0.046 & 0.053 & -0.015 & -0.051 & -0.060 & -0.069 \\
\hline & $(0.09)$ & $(0.55)$ & $(0.36)$ & $(0.31)$ & $(0.59)$ & $(0.09)$ & $(0.05)$ & $(0.03)$ \\
\hline \multirow[t]{2}{*}{ Growth } & -0.143 & -0.154 & -0.127 & -0.115 & -0.055 & -0.063 & -0.025 & -0.017 \\
\hline & $(0.17)$ & $(0.14)$ & $(0.22)$ & $(0.27)$ & $(0.41)$ & $(0.34)$ & $(0.71)$ & $(0.80)$ \\
\hline \multirow[t]{2}{*}{ SalesGrowth } & 0.030 & 0.030 & 0.030 & 0.030 & 0.038 & 0.037 & 0.036 & 0.037 \\
\hline & $(0.19)$ & $(0.18)$ & $(0.17)$ & $(0.17)$ & $(0.09)$ & $(0.10)$ & $(0.11)$ & $(0.10)$ \\
\hline \multirow[t]{2}{*}{ NOA } & -0.059 & -0.046 & -0.053 & -0.055 & -0.073 & -0.059 & -0.062 & -0.059 \\
\hline & $(0.28)$ & $(0.40)$ & $(0.34)$ & $(0.32)$ & $(0.04)$ & $(0.09)$ & $(0.08)$ & $(0.09)$ \\
\hline \multirow[t]{2}{*}{ Shares } & -0.113 & -0.117 & -0.143 & -0.165 & 0.032 & 0.016 & 0.026 & 0.029 \\
\hline & $(0.11)$ & $(0.11)$ & $(0.05)$ & $(0.02)$ & $(0.43)$ & $(0.69)$ & $(0.52)$ & $(0.47)$ \\
\hline \multirow[t]{2}{*}{ Litigation } & 0.168 & 0.177 & 0.163 & 0.155 & 0.281 & 0.277 & 0.281 & 0.278 \\
\hline & $(0.08)$ & $(0.07)$ & $(0.09)$ & $(0.11)$ & $(<0.01)$ & $(<0.01)$ & $(<0.01)$ & $(<0.01)$ \\
\hline \multirow[t]{2}{*}{ ImplicitClaims } & 0.197 & 0.159 & 0.118 & 0.087 & 0.522 & 0.516 & 0.502 & 0.497 \\
\hline & $(0.07)$ & $(0.14)$ & $(0.28)$ & $(0.43)$ & $(<0.01)$ & $(<0.01)$ & $(<0.01)$ & $(<0.01)$ \\
\hline \multirow[t]{2}{*}{ AnalystFollowing } & 0.016 & 0.017 & 0.014 & 0.014 & 0.027 & 0.028 & 0.025 & 0.024 \\
\hline & $(0.07)$ & $(0.05)$ & $(0.12)$ & $(0.13)$ & $(<0.01)$ & $(<0.01)$ & $(<0.01)$ & $(<0.01)$ \\
\hline \multirow[t]{2}{*}{ ForecastDispersion } & -0.828 & -0.816 & -0.810 & -0.818 & -0.496 & -0.507 & -0.491 & -0.490 \\
\hline & $(0.01)$ & $(0.02)$ & $(0.01)$ & $(0.01)$ & $(0.02)$ & $(0.02)$ & $(0.02)$ & $(0.02)$ \\
\hline $\begin{array}{l}\text { Generalized pseudo } \\
\mathrm{R}^{2}\end{array}$ & $2.41 \%$ & $2.68 \%$ & $2.86 \%$ & $2.93 \%$ & $3.19 \%$ & $3.28 \%$ & $3.36 \%$ & $3.40 \%$ \\
\hline No. of Observations & 3,834 & 3,834 & 3,834 & 3,834 & 15,649 & 15,649 & 15,649 & 15,649 \\
\hline \multicolumn{9}{|c|}{$\begin{array}{l}\text { All variables are defined in Appendix A. The two-tailed p-values are presented in parentheses and are } \\
\text { computed using heteroskedasticity robust standard errors, clustered by firm. All continuous variables are } \\
\text { winzorized at } 1 \% \text { and } 99 \% \text { to mitigate the effect of outliers. For the sake of brevity, we do not report } \\
\text { coefficient estimates for year indicators. }\end{array}$} \\
\hline
\end{tabular}


Table 4 Panel A: Pearson correlations of main variables for the accounting misconduct test

\begin{tabular}{|c|c|c|c|c|c|c|c|c|c|c|c|c|}
\hline & & Misconduct & $V 1$ & $V 2$ & $V 3$ & V4 & $V 5$ & V6 & $V 7$ & $V 8$ & $V 9$ & $V 10$ \\
\hline$V 1$ & CFO_Promo_Incent & 0.149 & & & & & & & & & & \\
\hline$V 2$ & CFO_Equity_Incent & 0.040 & 0.251 & & & & & & & & & \\
\hline$V 3$ & CEO_Equity_Incent & -0.025 & 0.060 & 0.539 & & & & & & & & \\
\hline$V 4$ & CEO_Chair & -0.001 & 0.108 & -0.023 & 0.127 & & & & & & & \\
\hline$V 5$ & CEO_PaySlice & 0.131 & 0.655 & 0.115 & -0.044 & 0.049 & & & & & & \\
\hline V6 & $V P \_C F O \_$Ratio & -0.033 & -0.015 & 0.088 & -0.046 & -0.008 & 0.322 & & & & & \\
\hline$V 7$ & $\Delta$ Cash_Sale & 0.063 & 0.039 & 0.329 & 0.286 & -0.020 & -0.004 & -0.002 & & & & \\
\hline$V 8$ & $\triangle I B$ & -0.033 & 0.002 & 0.042 & 0.002 & -0.072 & 0.045 & 0.080 & 0.085 & & & \\
\hline$V 9$ & $\Delta I n v t$ & 0.081 & 0.054 & 0.012 & 0.027 & 0.002 & 0.067 & -0.001 & 0.300 & 0.052 & & \\
\hline V10 & $\Delta R e c t$ & 0.053 & -0.035 & 0.129 & 0.127 & 0.016 & -0.035 & 0.006 & 0.411 & 0.123 & 0.404 & \\
\hline$V 11$ & Rsst_Accruals & -0.023 & -0.014 & 0.155 & 0.208 & 0.023 & -0.007 & 0.078 & 0.419 & 0.206 & 0.296 & 0.410 \\
\hline
\end{tabular}

Correlations significant at the 5\% level or less appear in bold. All variables are defined in Appendix A. 
Table 4 Panel B: Conditional logistic regression of the likelihood of accounting misconduct on the CFO promotion-based incentives

\begin{tabular}{|c|c|c|c|c|c|c|c|c|}
\hline \multicolumn{9}{|c|}{ Dependent Variable $=$ Misconduct } \\
\hline \multirow{2}{*}{ Variables } & \multicolumn{4}{|c|}{ pre-SOX } & \multicolumn{4}{|c|}{ post-SOX } \\
\hline & $(1)$ & (2) & (3) & (4) & (5) & (6) & (7) & $(8)$ \\
\hline \multirow[t]{2}{*}{ Intercept } & -0.864 & -3.001 & -3.092 & -3.144 & -0.776 & -1.594 & -1.587 & -1.209 \\
\hline & $(<0.01)$ & $(<0.01)$ & $(<0.01)$ & $(<0.01)$ & $(<0.01)$ & $(0.04)$ & $(0.04)$ & $(0.16)$ \\
\hline \multirow{2}{*}{ CFO_Promo_Incent } & & 0.289 & 0.311 & 0.229 & & 0.115 & 0.113 & 0.103 \\
\hline & & $(<0.01)$ & $(<0.01)$ & $(0.02)$ & & $(0.26)$ & $(0.28)$ & $(0.49)$ \\
\hline \multirow[t]{2}{*}{ CFO_Equity_Incent } & 0.290 & & -0.749 & -0.659 & 0.425 & & 0.096 & 0.542 \\
\hline & $(0.68)$ & & $(0.37)$ & $(0.51)$ & $(0.68)$ & & $(0.93)$ & $(0.62)$ \\
\hline \multirow[t]{2}{*}{ CEO_Equity_Incent } & & & & 0.019 & & & & -1.050 \\
\hline & & & & $(0.97)$ & & & & $(0.09)$ \\
\hline \multirow[t]{2}{*}{ CEO_Chair } & & & & 0.255 & & & & -0.374 \\
\hline & & & & $(0.25)$ & & & & $(0.16)$ \\
\hline \multirow[t]{2}{*}{ CEO_PaySlice } & & & & 1.182 & & & & 0.321 \\
\hline & & & & $(0.20)$ & & & & $(0.81)$ \\
\hline \multirow[t]{2}{*}{$\Delta$ Cash_Sales } & 0.313 & 0.276 & 0.370 & 0.411 & 0.052 & 0.036 & 0.031 & 0.006 \\
\hline & $(0.27)$ & $(0.35)$ & $(0.24)$ & $(0.19)$ & $(0.93)$ & $(0.95)$ & $(0.96)$ & (0.99) \\
\hline \multirow[t]{2}{*}{$\Delta$ Earnings } & -1.598 & -1.686 & -1.741 & -1.828 & 1.212 & 1.337 & 1.315 & 1.169 \\
\hline & $(0.11)$ & $(0.11)$ & $(0.10)$ & $(0.10)$ & $(0.40)$ & $(0.36)$ & $(0.37)$ & $(0.42)$ \\
\hline \multirow[t]{2}{*}{ AInventory } & 2.838 & 2.001 & 1.468 & 1.462 & 10.736 & 10.587 & 10.588 & 10.549 \\
\hline & $(0.32)$ & $(0.49)$ & $(0.62)$ & $(0.63)$ & $(0.05)$ & $(0.05)$ & $(0.05)$ & $(0.04)$ \\
\hline \multirow[t]{2}{*}{$\triangle$ Recievables } & 2.409 & 3.145 & 3.252 & 3.272 & 0.580 & 1.058 & 1.025 & 1.729 \\
\hline & $(0.29)$ & $(0.19)$ & $(0.18)$ & $(0.18)$ & $(0.87)$ & $(0.76)$ & $(0.77)$ & $(0.64)$ \\
\hline \multirow[t]{2}{*}{ Rsst_Accruals } & -0.517 & -0.386 & -0.352 & -0.425 & -2.476 & -2.556 & -2.553 & -2.377 \\
\hline & $(0.41)$ & $(0.53)$ & $(0.56)$ & $(0.49)$ & $(0.02)$ & $(0.01)$ & $(0.01)$ & $(0.03)$ \\
\hline Generalized pseudo R2 & $1.97 \%$ & $5.68 \%$ & $5.85 \%$ & $6.43 \%$ & $2.77 \%$ & $3.17 \%$ & $3.17 \%$ & $5.10 \%$ \\
\hline No. of Observations & 470 & 470 & 470 & 470 & 330 & 330 & 330 & 330 \\
\hline
\end{tabular}


Table 5 Panel A: Pearson correlations of main variables for the real earnings management test

\begin{tabular}{|c|c|c|c|c|c|c|c|c|c|c|c|c|c|c|c|c|}
\hline & & RM_Proxy & $V 1$ & $V 2$ & $V 3$ & $V 4$ & $V 5$ & V6 & $V 7$ & $V 8$ & $V 9$ & V10 & V10 & V10 & V10 & $V 11$ \\
\hline$V 1$ & RM_CFO & 0.669 & & & & & & & & & & & & & & \\
\hline$V 2$ & RM_Prod & 0.849 & 0.317 & & & & & & & & & & & & & \\
\hline$V 3$ & RM_DiscExp & -0.179 & -0.400 & -0.230 & & & & & & & & & & & & \\
\hline$V 4$ & CFO_Promo_Incent & -0.031 & -0.047 & -0.009 & 0.002 & & & & & & & & & & & \\
\hline V5 & CFO_Equity_Incent & -0.116 & -0.102 & -0.092 & -0.004 & 0.207 & & & & & & & & & & \\
\hline V6 & CEO_Equity_Incent & -0.111 & -0.099 & -0.088 & -0.006 & 0.124 & 0.508 & & & & & & & & & \\
\hline$V 7$ & CEO_Chair & 0.009 & -0.007 & 0.010 & 0.026 & 0.096 & 0.086 & 0.223 & & & & & & & & \\
\hline$V 8$ & CEO_PaySlice & 0.009 & -0.010 & 0.017 & 0.013 & 0.626 & 0.051 & -0.009 & 0.060 & & & & & & & \\
\hline$V 9$ & VP_CFO_Ratio & 0.012 & 0.004 & 0.014 & 0.007 & -0.065 & 0.065 & -0.083 & -0.050 & 0.291 & & & & & & \\
\hline V10 & Size & 0.063 & 0.011 & 0.079 & 0.031 & 0.630 & 0.202 & 0.111 & 0.131 & 0.162 & -0.021 & & & & & \\
\hline V11 & StdCashFlow & -0.051 & 0.000 & -0.060 & -0.045 & -0.186 & -0.064 & -0.035 & -0.072 & -0.070 & -0.019 & -0.390 & & & & \\
\hline V12 & StdRev & 0.054 & 0.017 & 0.060 & 0.018 & -0.119 & -0.046 & $-\mathbf{0 . 0 3 0}$ & -0.034 & -0.040 & 0.004 & -0.220 & 0.403 & & & \\
\hline V13 & StdSalesGrowth & -0.029 & -0.016 & -0.019 & -0.032 & -0.064 & 0.027 & 0.023 & -0.043 & -0.031 & -0.010 & -0.154 & 0.384 & 0.254 & & \\
\hline V14 & Oldfirm & 0.069 & 0.031 & 0.071 & 0.024 & 0.166 & -0.008 & -0.085 & 0.077 & 0.075 & 0.024 & 0.331 & -0.208 & -0.137 & -0.199 & \\
\hline V15 & Leverage & 0.112 & 0.080 & 0.101 & 0.030 & 0.203 & -0.068 & -0.132 & 0.070 & 0.087 & 0.013 & 0.376 & -0.094 & 0.033 & -0.094 & 0.162 \\
\hline
\end{tabular}

Correlations significant at the 5\% level or less appear in bold. All variables are defined in Appendix A. 
Table 5 Panel B: OLS regression of the real earnings management on the CFO promotion-based incentives

\begin{tabular}{|c|c|c|c|c|c|c|c|c|}
\hline \multirow{3}{*}{ Variables } & \multicolumn{8}{|c|}{ Dependent Variable $=$ RM_Proxy } \\
\hline & \multicolumn{3}{|c|}{ pre-SOX } & \multirow[b]{2}{*}{$(4)$} & \multicolumn{3}{|c|}{ post-SOX } & \multirow[b]{2}{*}{$(8)$} \\
\hline & $(1)$ & $(2)$ & (3) & & $(5)$ & $(6)$ & $(7)$ & \\
\hline \multirow[t]{2}{*}{ Intercept } & -0.115 & -0.104 & -0.104 & -0.108 & $\begin{array}{c}-0.084 \\
\end{array}$ & -0.075 & -0.075 & -0.074 \\
\hline & $(<0.01)$ & $(<0.01)$ & $(<0.01)$ & $(<0.01)$ & $(<0.01)$ & $(<0.01)$ & $(<0.01)$ & $(<0.01)$ \\
\hline \multirow{2}{*}{ CFO_Promo_Incent } & & -0.003 & -0.003 & -0.007 & & -0.002 & -0.002 & -0.005 \\
\hline & & $(<0.01)$ & $(<0.01)$ & $(<0.01)$ & & $(0.04)$ & $(0.04)$ & $(<0.01)$ \\
\hline \multirow[t]{2}{*}{ CFO_Equity_Incent } & -0.006 & & -0.003 & -0.007 & -0.023 & & -0.023 & -0.017 \\
\hline & $(0.65)$ & & $(0.82)$ & $(0.58)$ & $(0.04)$ & & $(0.04)$ & $(0.15)$ \\
\hline \multirow[t]{2}{*}{ CEO_Equity_Incent } & & & & 0.009 & & & & -0.009 \\
\hline & & & & $(0.16)$ & & & & $(0.11)$ \\
\hline \multirow[t]{2}{*}{ CEO_Chair } & & & & 0.003 & & & & 0.001 \\
\hline & & & & $(0.12)$ & & & & $(0.54)$ \\
\hline \multirow[t]{2}{*}{ CEO_Payslice } & & & & 0.049 & & & & 0.039 \\
\hline & & & & $(<0.01)$ & & & & $(<0.01)$ \\
\hline \multirow[t]{2}{*}{ Size } & 0.002 & 0.004 & 0.004 & 0.005 & 0.002 & 0.003 & 0.003 & 0.005 \\
\hline & $(0.04)$ & $(<0.01)$ & $(<0.01)$ & $(<0.01)$ & $(0.02)$ & $(<0.01)$ & $(<0.01)$ & $(<0.01)$ \\
\hline \multirow[t]{2}{*}{ StdCashFlow } & 0.052 & 0.057 & 0.057 & 0.066 & -0.043 & -0.038 & -0.042 & -0.039 \\
\hline & $(0.13)$ & $(0.09)$ & $(0.09)$ & $(0.05)$ & $(0.23)$ & $(0.29)$ & $(0.25)$ & $(0.28)$ \\
\hline \multirow[t]{2}{*}{ StdRev } & 0.065 & 0.065 & 0.065 & 0.065 & 0.048 & 0.048 & 0.048 & 0.048 \\
\hline & $(<0.01)$ & $(<0.01)$ & $(<0.01)$ & $(<0.01)$ & $(<0.01)$ & $(<0.01)$ & $(<0.01)$ & $(<0.01)$ \\
\hline \multirow[t]{2}{*}{ StdSalesGrowth } & 0.006 & 0.006 & 0.006 & 0.007 & 0.003 & 0.003 & 0.003 & 0.003 \\
\hline & $(0.26)$ & $(0.23)$ & $(0.22)$ & $(0.19)$ & $(0.66)$ & $(0.66)$ & $(0.63)$ & $(0.61)$ \\
\hline \multirow[t]{2}{*}{ Oldfirm } & 0.002 & 0.001 & 0.001 & 0.001 & 0.004 & 0.003 & 0.003 & 0.003 \\
\hline & $(0.52)$ & $(0.59)$ & $(0.60)$ & $(0.62)$ & $(0.07)$ & $(0.09)$ & $(0.08)$ & $(0.13)$ \\
\hline \multirow[t]{2}{*}{ Leverage } & -0.014 & -0.013 & -0.012 & -0.012 & -0.025 & -0.025 & -0.024 & -0.024 \\
\hline & $(0.07)$ & $(0.09)$ & $(0.10)$ & $(0.11)$ & $(<0.01)$ & $(<0.01)$ & $(<0.01)$ & $(<0.01)$ \\
\hline $\mathrm{R}^{2}$ & $27 \%$ & $27.17 \%$ & $27.17 \%$ & $27.58 \%$ & $14.99 \%$ & $14.99 \%$ & $15.02 \%$ & $15.08 \%$ \\
\hline No. of Observations & 7,175 & 7,175 & 7,175 & 7,175 & 18,398 & 18,398 & 18,398 & 18,398 \\
\hline \multicolumn{9}{|c|}{$\begin{array}{l}\text { All variables are defined in Appendix A. The two-tailed p-values are presented in parentheses and are } \\
\text { computed using heteroskedasticity robust standard errors, clustered by firm. All continuous variables are } \\
\text { winzorized at } 1 \% \text { and } 99 \% \text { to mitigate the effect of outliers. For the sake of brevity, we do not report } \\
\text { coefficient estimates for MarketToBookDecile indicators, year indicators, exchange indicators, G index } \\
\text { dummies, and the Fama and French (1997) industry indicators. }\end{array}$} \\
\hline
\end{tabular}


Table 6 Panel A OLS regression of the absolute value of discretionary accruals on the CFO promotionbased incentives conditional on CEO Turnover

\begin{tabular}{|c|c|c|c|c|}
\hline \multirow{3}{*}{ Variables } & \multicolumn{4}{|c|}{ Dependent Variable $=\mid$ Discretionary Accruals $\mid$} \\
\hline & \multicolumn{2}{|c|}{ pre-SOX } & \multicolumn{2}{|c|}{ post-SOX } \\
\hline & (1) & $(2)$ & (3) & (4) \\
\hline \multirow[t]{2}{*}{ Intercept } & 0.021 & 0.018 & 0.053 & 0.051 \\
\hline & $(0.16)$ & $(0.24)$ & $(<0.01)$ & $(<0.01)$ \\
\hline \multirow[t]{2}{*}{ CFO_Promo_Incent } & 0.005 & 0.006 & 0.001 & 0.002 \\
\hline & $(<0.01)$ & $(<0.01)$ & $(0.03)$ & $(<0.01)$ \\
\hline \multirow[t]{2}{*}{ CEO_Turnover } & -0.015 & & 0.008 & \\
\hline & $(0.08)$ & & $(0.16)$ & \\
\hline \multirow[t]{2}{*}{ CEO_Turnoverx $C F O \_P r o m o \_I n c e n t$} & 0.003 & & -0.001 & \\
\hline & $(0.03)$ & & $(0.12)$ & \\
\hline \multirow[t]{2}{*}{ CFO_VP_ratio } & & 0.003 & & 0.003 \\
\hline & & $(0.17)$ & & $(<0.01)$ \\
\hline \multirow[t]{2}{*}{ CEO_Chair } & 0.003 & 0.003 & 0.001 & 0.001 \\
\hline & $(0.06)$ & $(0.05)$ & $(0.16)$ & $(0.18)$ \\
\hline \multirow[t]{2}{*}{ CEO_Payslice } & -0.024 & -0.036 & -0.009 & -0.022 \\
\hline & $(<0.01)$ & $(<0.01)$ & $(0.06)$ & $(<0.01)$ \\
\hline \multirow[t]{2}{*}{ Size } & -0.006 & -0.006 & -0.004 & -0.004 \\
\hline & $(<0.01)$ & $(<0.01)$ & $(<0.01)$ & $(<0.01)$ \\
\hline \multirow[t]{2}{*}{ StdCashFlow } & 0.163 & 0.169 & 0.182 & 0.186 \\
\hline & $(<0.01)$ & $(<0.01)$ & $(<0.01)$ & $(<0.01)$ \\
\hline \multirow[t]{2}{*}{ StdRev } & 0.049 & 0.048 & 0.030 & 0.030 \\
\hline & $(<0.01)$ & $(<0.01)$ & $(<0.01)$ & $(<0.01)$ \\
\hline \multirow[t]{2}{*}{ StdSalesGrowth } & 0.005 & 0.004 & 0.004 & 0.004 \\
\hline & $(0.11)$ & $(0.19)$ & $(0.10)$ & $(0.09)$ \\
\hline \multirow[t]{2}{*}{ Oldfirm } & -0.003 & -0.003 & -0.001 & -0.001 \\
\hline & $(0.10)$ & $(0.08)$ & $(0.46)$ & $(0.46)$ \\
\hline \multirow[t]{2}{*}{ Leverage } & 0.025 & 0.024 & 0.009 & 0.008 \\
\hline & $(<0.01)$ & $(<0.01)$ & $(<0.01)$ & $(<0.01)$ \\
\hline$R^{2}$ & $18.12 \%$ & $18.04 \%$ & $12.54 \%$ & $12.65 \%$ \\
\hline No. of Observations & 8,266 & 7,811 & 20,210 & 19.021 \\
\hline \multicolumn{5}{|c|}{$\begin{array}{l}\text { All variables are defined in Appendix A. The two-tailed p-values are presented in parentheses and are } \\
\text { computed using heteroskedasticity robust standard errors, clustered by firm. All continuous variables are } \\
\text { winzorized at } 1 \% \text { and } 99 \% \text { to mitigate the effect of outliers. For the sake of brevity, we do not report } \\
\text { coefficient estimates for MarketToBookDecile indicators, year indicators, exchange indicators, G index } \\
\text { dummies, and the Fama and French (1997) industry indicators. }\end{array}$} \\
\hline
\end{tabular}


Table 6 Panel B Logistic analysis of the likelihood of meeting or beating analysts' forecasts on the CFO promotion-based incentives conditional on CEO Turnover

\begin{tabular}{|c|c|c|c|c|}
\hline \multirow{3}{*}{ Variables } & \multicolumn{4}{|c|}{ Dependent Variable $=$ Positive Surprise } \\
\hline & \multicolumn{2}{|c|}{ pre-SOX } & \multicolumn{2}{|c|}{ post-SOX } \\
\hline & $(1)$ & $(2)$ & (3) & (4) \\
\hline \multirow[t]{2}{*}{ Intercept } & 0.127 & -0.590 & -0.343 & -0.726 \\
\hline & $(0.72)$ & $(0.11)$ & $(0.11)$ & $(<0.01)$ \\
\hline \multirow[t]{2}{*}{ CFO_Promo_Incent } & 0.180 & 0.297 & 0.139 & 0.217 \\
\hline & $(<0.01)$ & $(<0.01)$ & $(<0.01)$ & $(<0.01)$ \\
\hline \multirow[t]{2}{*}{ CEO_Turnover } & -1.376 & & -0.242 & \\
\hline & $(0.01)$ & & $(0.49)$ & \\
\hline \multirow[t]{2}{*}{ CEO_Turnover $\times$ CFO_Promo_Incent } & 0.149 & & 0.013 & \\
\hline & $(0.06)$ & & $(0.76)$ & \\
\hline \multirow[t]{2}{*}{ CFO_VP_ratio } & & 0.330 & & 0.202 \\
\hline & & $(<0.01)$ & & $(<0.01)$ \\
\hline \multirow[t]{2}{*}{ CEO_Chair } & 0.051 & 0.043 & 0.089 & 0.074 \\
\hline & $(0.53)$ & $(0.61)$ & $(0.05)$ & $(0.11)$ \\
\hline \multirow{2}{*}{ CEO_Payslice } & -0.720 & -1.430 & -0.320 & -1.109 \\
\hline & $(0.14)$ & $(0.02)$ & $(0.29)$ & $(<0.01)$ \\
\hline \multirow[t]{2}{*}{ Size } & 0.024 & -0.009 & -0.061 & -0.075 \\
\hline & $(0.64)$ & $(0.86)$ & $(0.05)$ & $(0.02)$ \\
\hline \multirow[t]{2}{*}{ Growth } & -0.142 & -0.098 & -0.057 & -0.051 \\
\hline & $(0.17)$ & $(0.36)$ & $(0.39)$ & $(0.46)$ \\
\hline \multirow[t]{2}{*}{ SalesGrowth } & 0.028 & 0.031 & 0.037 & 0.057 \\
\hline & $(0.21)$ & $(0.17)$ & $(0.11)$ & $(0.06)$ \\
\hline \multirow[t]{2}{*}{ NOA } & -0.043 & -0.067 & -0.058 & -0.068 \\
\hline & $(0.43)$ & $(0.23)$ & $(0.10)$ & $(0.06)$ \\
\hline \multirow[t]{2}{*}{ Shares } & -0.122 & -0.112 & 0.020 & 0.014 \\
\hline & $(0.09)$ & $(0.14)$ & $(0.61)$ & $(0.74)$ \\
\hline \multirow[t]{2}{*}{ Litigation } & 0.195 & 0.220 & 0.281 & 0.269 \\
\hline & $(0.04)$ & $(0.03)$ & $(<0.01)$ & $(<0.01)$ \\
\hline \multirow[t]{2}{*}{ ImplicitClaims } & 0.139 & 0.074 & 0.515 & 0.512 \\
\hline & $(0.20)$ & $(0.51)$ & $(<0.01)$ & $(<0.01)$ \\
\hline \multirow[t]{2}{*}{ AnalystFollowing } & 0.016 & 0.016 & 0.027 & 0.026 \\
\hline & $(0.07)$ & $(0.09)$ & $(<0.01)$ & $(<0.01)$ \\
\hline \multirow[t]{2}{*}{ ForecastDispersion } & -0.815 & -0.986 & -0.506 & -0.636 \\
\hline & $(0.01)$ & $(<0.01)$ & $(0.02)$ & $(<0.01)$ \\
\hline Generalized pseudo $\mathrm{R}^{2}$ & $3.21 \%$ & $3.16 \%$ & $3.37 \%$ & $3.55 \%$ \\
\hline No. of Observations & 3,834 & 3,684 & 15,649 & 14,792 \\
\hline \multicolumn{5}{|c|}{$\begin{array}{l}\text { All variables are defined in Appendix A. The two-tailed p-values are presented in parentheses and are } \\
\text { computed using heteroskedasticity robust standard errors, clustered by firm. All continuous variables are } \\
\text { winzorized at } 1 \% \text { and } 99 \% \text { to mitigate the effect of outliers. For the sake of brevity, we do not report } \\
\text { coefficient estimates for year indicators. }\end{array}$} \\
\hline
\end{tabular}


Table 6 Panel C logistic regression of the likelihood of accounting misconduct on the CFO promotionbased incentives conditional on CEO Turnover

\begin{tabular}{|c|c|c|c|c|}
\hline \multirow[b]{3}{*}{ Variables } & \multicolumn{4}{|c|}{ Dependent Variable $=$ Misconduct } \\
\hline & \multicolumn{2}{|c|}{ pre-SOX } & \multicolumn{2}{|c|}{ post-SOX } \\
\hline & $(1)$ & $(2)$ & $(3)$ & $(4)$ \\
\hline \multirow[t]{2}{*}{ Intercept } & -2.876 & -2.640 & -1.053 & -1.534 \\
\hline & $(<0.01)$ & $(<0.01)$ & $(0.25)$ & $(0.13)$ \\
\hline \multirow[t]{2}{*}{ CFO_Promo_Incent } & 0.110 & 0.150 & 0.012 & 0.111 \\
\hline & $(0.29)$ & $(0.13)$ & $(0.94)$ & $(0.51)$ \\
\hline \multirow[t]{2}{*}{ CEO_Turnover } & -0.473 & & -1.248 & \\
\hline & $(0.70)$ & & $(0.49)$ & \\
\hline \multirow[t]{2}{*}{ 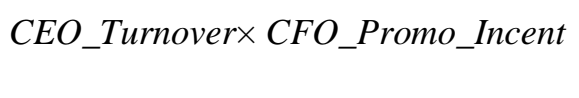 } & 0.164 & & 0.281 & \\
\hline & $(0.30)$ & & $(0.23)$ & \\
\hline \multirow[t]{2}{*}{ CFO_VP_ratio } & & -0.366 & & 0.011 \\
\hline & & $(0.07)$ & & $(0.97)$ \\
\hline \multirow[t]{2}{*}{ CEO_Chair } & 0.267 & 0.261 & -0.529 & -0.467 \\
\hline & $(0.24)$ & $(0.24)$ & $(0.05)$ & $(0.08)$ \\
\hline \multirow[t]{2}{*}{ CEO_PaySlice } & 2.073 & 2.202 & 0.837 & 0.593 \\
\hline & $(0.03)$ & $(0.04)$ & $(0.54)$ & $(0.70)$ \\
\hline \multirow[t]{2}{*}{$\Delta$ Cash_Sales } & 0.365 & 0.318 & 0.063 & -0.124 \\
\hline & $(0.20)$ & $(0.30)$ & $(0.92)$ & $(0.85)$ \\
\hline \multirow[t]{2}{*}{ DEarnings } & -1.461 & -1.125 & 0.807 & 0.998 \\
\hline & $(0.19)$ & $(0.32)$ & $(0.57)$ & $(0.49)$ \\
\hline \multirow[t]{2}{*}{ AInventory } & 2.097 & 2.560 & 10.793 & 9.582 \\
\hline & $(0.48)$ & $(0.40)$ & $(0.04)$ & $(0.08)$ \\
\hline \multirow[t]{2}{*}{$\Delta$ Recievables } & 3.401 & 2.528 & 1.582 & 1.310 \\
\hline & $(0.16)$ & $(0.29)$ & $(0.66)$ & $(0.72)$ \\
\hline \multirow[t]{2}{*}{ Rsst_Accruals } & -0.482 & -0.278 & -2.366 & -2.405 \\
\hline & $(0.44)$ & $(0.66)$ & $(0.03)$ & $(0.03)$ \\
\hline Generalized pseudo R2 & $8.45 \%$ & $6.85 \%$ & $7.29 \%$ & $4.18 \%$ \\
\hline No. of Observations & 470 & 446 & 330 & 307 \\
\hline
\end{tabular}


Table 6 Panel D OLS regression of the real earnings management on the CFO promotion-based incentives conditional on CEO Turnover

Dependent Variable $=$ RM_Proxy

\begin{tabular}{|c|c|c|c|c|}
\hline \multirow{2}{*}{ Variables } & \multicolumn{2}{|c|}{ pre-SOX } & \multicolumn{2}{|c|}{ post-SOX } \\
\hline & $(1)$ & $(2)$ & $(3)$ & $(4)$ \\
\hline \multirow[t]{2}{*}{ Intercept } & -0.101 & -0.108 & -0.076 & -0.068 \\
\hline & $(<0.01)$ & $(<0.01)$ & $(<0.01)$ & $(<0.01)$ \\
\hline \multirow[t]{2}{*}{ CFO_Promo_Incent } & -0.007 & -0.008 & -0.005 & -0.007 \\
\hline & $(<0.01)$ & $(<0.01)$ & $(<0.01)$ & $(<0.01)$ \\
\hline \multirow[t]{2}{*}{ CEO_Turnover } & -0.017 & & 0.002 & \\
\hline & $(0.15)$ & & $(0.91)$ & \\
\hline \multirow[t]{2}{*}{ 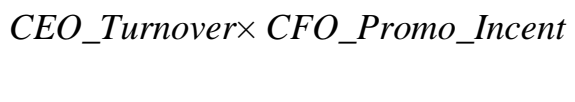 } & 0.002 & & -0.000 & \\
\hline & $(0.18)$ & & $(0.92)$ & \\
\hline \multirow[t]{2}{*}{ CFO_VP_ratio } & & -0.002 & & -0.004 \\
\hline & & $(0.25)$ & & $(0.10)$ \\
\hline \multirow[t]{2}{*}{ CEO_Chair } & 0.004 & 0.005 & 0.000 & 0.001 \\
\hline & $(0.06)$ & $(0.04)$ & $(0.94)$ & $(0.74)$ \\
\hline \multirow[t]{2}{*}{ CEO_Payslice } & 0.049 & 0.057 & 0.038 & 0.054 \\
\hline & $(<0.01)$ & $(<0.01)$ & $(<0.01)$ & $(<0.01)$ \\
\hline \multirow[t]{2}{*}{ Size } & 0.005 & 0.005 & 0.004 & 0.004 \\
\hline & $(<0.01)$ & $(<0.01)$ & $(<0.01)$ & $(<0.01)$ \\
\hline \multirow[t]{2}{*}{ StdCashFlow } & 0.065 & 0.058 & -0.035 & -0.046 \\
\hline & $(0.05)$ & $(0.09)$ & $(0.33)$ & $(0.22)$ \\
\hline \multirow[t]{2}{*}{ StdRev } & 0.065 & 0.066 & 0.048 & 0.049 \\
\hline & $(<0.01)$ & $(<0.01)$ & $(<0.01)$ & $(<0.01)$ \\
\hline \multirow[t]{2}{*}{ StdSalesGrowth } & 0.007 & 0.006 & 0.003 & 0.002 \\
\hline & $(0.16)$ & $(0.25)$ & $(0.65)$ & $(0.73)$ \\
\hline \multirow[t]{2}{*}{ Oldfirm } & 0.001 & 0.001 & 0.003 & 0.003 \\
\hline & $(0.71)$ & $(0.59)$ & $(0.11)$ & $(0.12)$ \\
\hline \multirow[t]{2}{*}{ Leverage } & -0.012 & -0.011 & -0.025 & -0.025 \\
\hline & $(0.10)$ & $(0.16)$ & $(<0.01)$ & $(<0.01)$ \\
\hline$R^{2}$ & $27.57 \%$ & $27.41 \%$ & $15.04 \%$ & $15.14 \%$ \\
\hline No. of Observations & 7,175 & 6,788 & 18,398 & 17,328 \\
\hline
\end{tabular}

All variables are defined in Appendix A. The two-tailed p-values are presented in parentheses and are computed using heteroskedasticity robust standard errors, clustered by firm. All continuous variables are winzorized at $1 \%$ and $99 \%$ to mitigate the effect of outliers. For the sake of brevity, we do not report coefficient estimates for MarketToBookDecile indicators, year indicators, exchange indicators, G index dummies, and the Fama and French (1997) industry indicators. 